Article

\title{
Using Soil Stratigraphy and Tephrochronology to Understand the Origin, Age, and Classification of a Unique Late Quaternary Tephra-Derived Ultisol in Aotearoa New Zealand
}

\author{
David J. Lowe \\ School of Science (Earth Sciences), University of Waikato, Private Bag 3105, Hamilton 3240, New Zealand; \\ david.lowe@waikato.ac.nz; Tel.: +64-7-838-4438
}

Received: 31 December 2018; Accepted: 31 January 2019; Published: 20 February 2019

\begin{abstract}
In this article, I show how an Ultisol, representative of a globally-important group of soils with clay-rich subsoils, low base saturation, and low fertility, in the central Waikato region in northern North Island, can be evaluated using soil stratigraphy and tephrochronology to answer challenging questions about its genesis, age and classification. The Kainui soil, a Typic Kandiudult (Soil Taxonomy) and Buried-granular Yellow Ultic Soil (New Zealand Soil Classification), occurs on low rolling hills of Mid-Quaternary age mainly in the Hamilton lowlands in, and north and northeast of, Hamilton city. It is a composite, multi-layered tephra-derived soil consisting of two distinct parts, upper and lower. The upper part is a coverbed typically c. $0.4-0.7 \mathrm{~m}$ in thickness (c. $0.6 \mathrm{~m}$ on average) comprising numerous late Quaternary rhyolitic and andesitic tephras that have been accumulating incrementally since c. $50 \mathrm{ka}$ (the age of Rotoehu Ash at the coverbed's base) whilst simultaneously being pedogenically altered (i.e., forming soil horizons) via developmental upbuilding pedogenesis during Marine Oxygen Isotope Stages (MOIS) 3-1. Any original depositional (fall) bedding has been almost entirely masked by pedogenic alteration. Sediments in lakes aged c. 20 ka adjacent to the low hills have preserved around 40 separate, thin, macroscopic tephra-fall beds mainly rhyolitic in composition, and equivalent subaerial deposits together form the upper c. $30 \mathrm{~cm}$ of the coverbed. Okareka (c. 21.8 ka), Okaia (c. 28.6 ka), Tāhuna (c. 39.3 ka) and (especially) Rotoehu tephras make up the bulk of the lower c. $30 \mathrm{~cm}$ of the coverbed. Tephra admixing has occurred throughout the coverbed because of soil upbuilding processes. Moderately well drained, this upper profile is dominated by halloysite (not allophane) in the clay fraction because of limited desilication. In contrast, Otorohanga soils, on rolling hills to the south of Hamilton, are formed in equivalent but thicker $(>c .0 .8 \mathrm{~m})$ late Quaternary tephras $\leq \mathrm{c} .50 \mathrm{ka}$ that are somewhat more andesitic although predominantly rhyolitic overall. These deeper soils are well drained with strong desilication and thus are allophanic, generating Typic Hapludands. Ubiquitous redox features, together with short-lived contemporary reduction observed in the lower coverbed of a Kainui soil profile, indicate that the Kainui soil in general is likely to be saturated by perching for several days, or near saturation for several months, each year. The perching occurs because the coverbed overlies a slowly-permeable, buried, clay-rich paleosol on upper Hamilton Ash beds, >c. $50 \mathrm{ka}$ in age, which makes up the lower part of the two-storeyed Kainui soil. The coverbed-paleosol boundary is a lithologic discontinuity (unconformity). Irregular in shape, it represents a tree-overturn paleosurface that may be c. $74 \mathrm{ka}$ in age (MOIS $5 / 4$ boundary). The buried paleosol is markedly altered and halloysitic with relict clay skins (forming paleo-argillic and/or paleo-kandic horizons) and redoximorphic features. It is inferred to have formed via developmental upbuilding pedogenesis during the Last Interglacial (MOIS 5e). The entire Hamilton Ash sequence, c. $3 \mathrm{~m}$ in thickness and overlain unconformably by Rotoehu Ash and underlain by c. 340-ka Rangitawa Tephra at the base, represents a thick composite (accretionary) set of clayey, welded paleosols developed by upbuilding pedogenesis from MOIS 10 to 5 .
\end{abstract}


Keywords: pedology; paleopedology; paleosol; upbuilding pedogenesis; soil welding; tephra; tephrostratigraphy; tephrochronology; soil stratigraphy; pedostratigraphy; lake sediments; clay minerals; halloysite; allophane; Rotoehu Ash; Rangitawa Tephra; Hamilton Ash; soil classification; Ultisols; Ultic Soils; Waikato region

\section{Introduction}

\subsection{Ultisols Globally and in New Zealand}

Ultisols, as the name suggests, comprise an important group of relatively old and weathered soils characterized by (i) the translocation (illuviation) of clays with depth (accumulating to form clay-rich argillic and kandic horizons, two so-called diagnostic horizons used to characterize soils and enable them to be classified), and (ii) leaching of non-acid cations from the profile so that a relatively acid subsoil horizon has $<35 \%$ of the exchange capacity satisfied with non-acid cations (previously known as base cations, namely $\mathrm{Ca}^{2+}, \mathrm{Mg}^{2+}, \mathrm{K}^{+}$and $\mathrm{Na}^{+}$). Ultisols thus have a clay-rich subsoil with low non-acid saturation (low base saturation) and generally low fertility [1-3].

The term 'Ultisol' refers to one of 12 soil orders used in a hierarchical grouping of natural soil bodies in the international soil classification system known as Soil Taxonomy (ST) [1]. ST is fundamentally based on measurable and observable soil properties, key criteria being the occurrence or not of certain diagnostic horizons or features within defined parts of the soil profile (referred to as control sections), such as the presence of an argillic or kandic horizon in the case of Ultisols, rather than being based on presumed mechanisms of soil genesis. The subclasses of the Ultisol order are defined by a wide range of diagnostic horizons or features other than those used to define the order, in turn reflecting numerous processes and conditions associated with the order [4].

Ultisols occupy about $8.1 \%$ of the Earth's land surface and are very common in tropical areas (where c. $80 \%$ of Ultisols occur), the remainder occurring in temperate environments [5]. They are often formed on old land surfaces, usually under forest vegetation (under natural conditions) and with a humid climate: c. $58 \%$ of Ultisols have an udic moisture regime (well-distributed rainfall annually) and c. $42 \%$ an ustic moisture regime (rainfall is limited for part of the year) [6]. Such old land surfaces are commonly gently undulating to flat and so Ultisols, although not as naturally fertile as soils of various other soil orders (such as Alfisols and Mollisols), have been used by farmers for millennia and can be very productive with lime and/or fertilizer input. The coarser-textured upper profile, largely adequate rainfall and warmth and long growing seasons, provide generally good conditions for cropping [3], as long as the low nutrient status and (usually) high subsoil acidity are overcome as needed [2]. It was concluded in Reference [5] (p. 33.175) that "Only with a thorough understanding of the genesis, properties and response to management of these soils can the productivity of this valuable resource be maintained and enhanced."

In New Zealand, Ultisols make up about $4.2 \%$ of the land area [7], the vast majority occurring in the (warmer) North Island rather than South Island [8,9]. A large proportion of the order is taken up by soils derived from weathered tephras, which are the explosively-erupted, unconsolidated pyroclastic (fragmental) products of volcanic eruptions including volcanic ash [10], of Middle to Late Quaternary age. Most are referred to as Granular Soils in the New Zealand Soil Classification (NZSC) [11]. They are typically clay-rich, acidic, soils dominated by kaolin-subgroup clays together with smaller amounts of iron oxides and oxyhydroxides and other minerals that may include subordinate gibbsite, allophane, and vermiculite. Hence they are usually sticky and plastic but well-structured where iron oxides and other (non-kaolin-subgroup) clays are sufficient to meliorate the stickiness and improve the soil fabric. 


\subsection{Using Tephrochronology to Facilitate Study of Late Quaternary Ultisols in New Zealand}

An important advantage associated with these soils in New Zealand is that their ages are able to be constrained to some degree by tephrochronology, a unique stratigraphic method for linking and dating sequences or events [10,12], which thus provides a framework for studies on rates of pedogenesis [13,14], paleopedology (the study of paleosols, which are soils of an environment or landscape of the past, usually buried) [15-19], and paleoclimatology [20-22]. The role of soil stratigraphy - the interplay between geological deposition, soil formation, buried soils (paleosols), and their chronological relationships (sometimes called pedostratigraphy, for example [23-25]) - is therefore enhanced through tephrostratigraphy that underpins and informs the application of tephrochronology $[10,26,27]$.

Many of the Granular Soils occur in the northern North Island area generally between Hamilton and Auckland and to the northeast of Hamilton including on foothills of the Kaimai Range (Figure 1), on old, strongly weathered tephra layers that had been erupted from various rhyolitic volcanic centres in central Taupō Volcanic Zone since more than c. 50,000 years ago (50 ka) (Figure 1) [8,28,29]; for reviews of the volcanic record see [30,31]. (All ages used in the text are in calendar or calibrated years.) That these older beds form modern (surface) soils is because the younger mantling tephra layers prevalent in the central North Island $[19,32]$ have become sufficiently thin at distal locations, or have been eroded from unstable or steep sites, to allow the older deposits and paleosols to emerge at the land surface (exhumation). Their occurrence in the warmer parts of northern North Island [33] generally confers an advantageous growing environment. In Hamilton, the mean annual soil (not air) temperature is $14.9^{\circ} \mathrm{C}$, which is just within the range for the so-called mesic soil temperature regime (8 to $15^{\circ} \mathrm{C}$ ) of ST [34]. North and northeast of Hamilton in lowland areas (including Hauraki) the soil temperature regime falls into the thermic range $\left(15\right.$ to $\left.22{ }^{\circ} \mathrm{C}\right)$. The temperature regimes are an average of the soil temperature measured at $0.5 \mathrm{~m}$ depth mid-monthly [34]. 

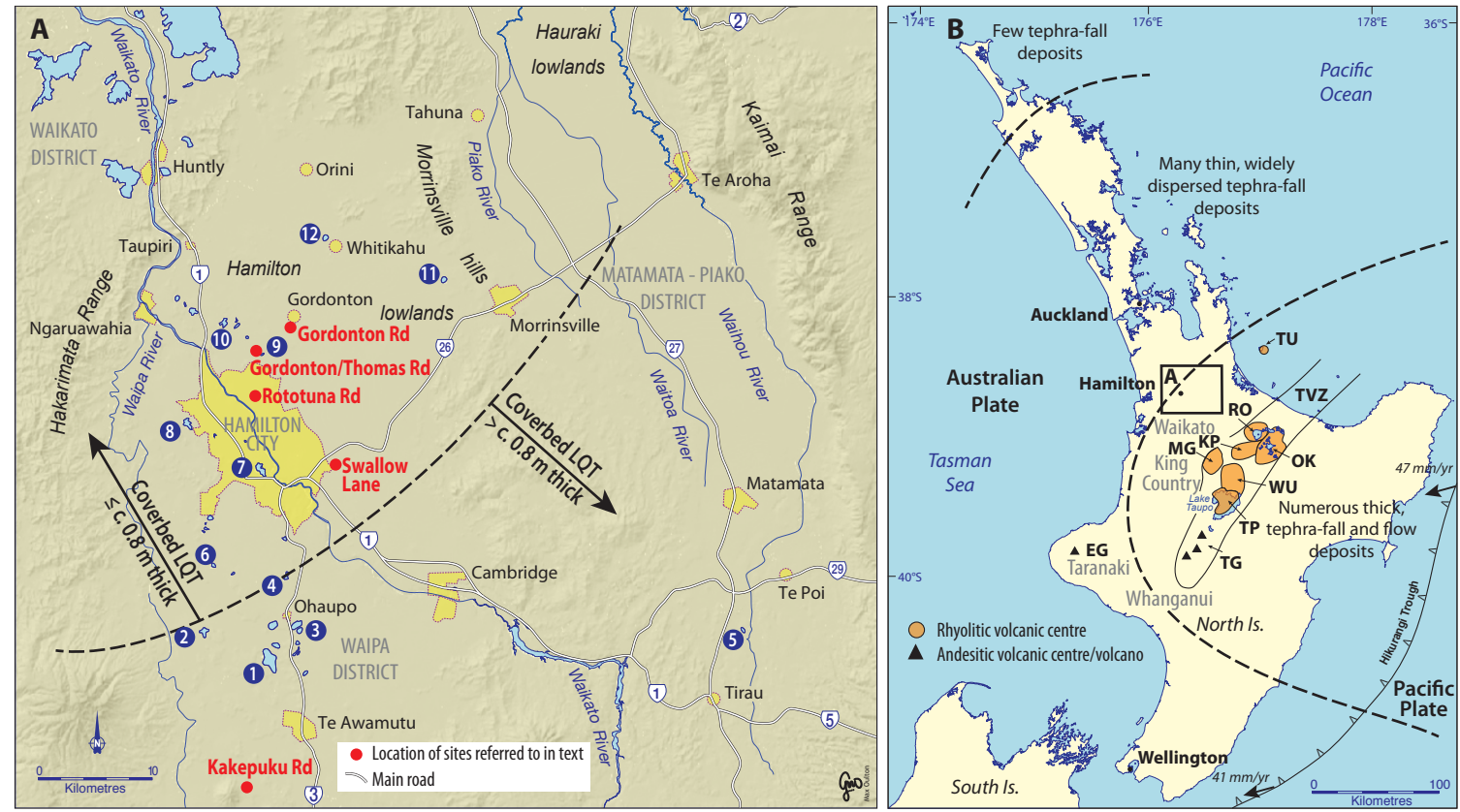

Figure 1. (A) Map of the central Waikato region, northern North Island, showing the locations of sites illustrating the Kainui soil and its associated stratigraphy and buried paleosols in the Hamilton lowlands. Some physiographic features are shown and local authority districts are also named. The dashed line marks the approximate boundary, c. $0.8 \mathrm{~m}$, of the total thickness of the coverbed mantle of late Quaternary tephras (LQT), based on [35] (pp. 35-36). It marks an Andisol-Ultisol threshold, with Andisols generally formed to the south and Ultisols to the north. Late Quaternary lakes that have been cored, and which contain a record of rhyolitic and andesitic tephra deposition in the region since c. 22-20 ka [18,36,37], are numbered as follows: 1, Ngāroto; 2, Mangakaware; 3, Rotomanuka; 4, Maratoto; 5, Okoroire; 6, Mangahia; 7, Rotoroa; 8, Rotokauri; 9, Tunawhakapeke (drained); 10, Kainui; 11, Leesons; 12, Rotokaraka. (B) Map of North Island, New Zealand, showing its general plate tectonic setting and all but two of the rhyolite volcanic centres (calderas) active in the Quaternary in the central Taupō Volcanic Zone (TVZ): OK, Okataina; RO, Rotorua; KP, Kapenga; MG, Mangakino; WU, Whakamaru; TP, Taupō. Offshore Tuhua Volcanic Centre (TU) (Mayor Island) and andesitic volcanoes at Tongariro Volcanic Centre (TG) and Egmont volcano (EG) (Mt Taranaki) are also shown (after [38]). Some regions are named and a generalized thickness pattern of soil-forming tephra deposits is depicted in three broad zones reflecting proximity to source volcanoes and the influence of prevailing westerlies (after [19,39]).

\subsection{Aim and Outline of Paper}

The focus of this article is on a unique and elucidative Ultisol, the Kainui silt loam ('Kainui soil' hereafter), formed on weathered, multi-layered tephras in the central Waikato region (mainly the Hamilton lowlands) in northern North Island (Figure 1). Why should the Kainui soil be of interest to a global audience? To paraphrase Churchill, it is a riddle wrapped in a mystery inside an enigma. I can think of no better soil anywhere that provides such interest and understanding at the heart of both pedology and paleopedology in a tephra-dominated Quaternary setting: puzzling origins, perplexing mineralogy and problematic classification. As will be discussed below, the Kainui soil is derived from multiple Late Quaternary tephra layers and comprises a profile with distinctive upper and lower parts within c. $1 \mathrm{~m}$ of the land surface (Figure 2). 


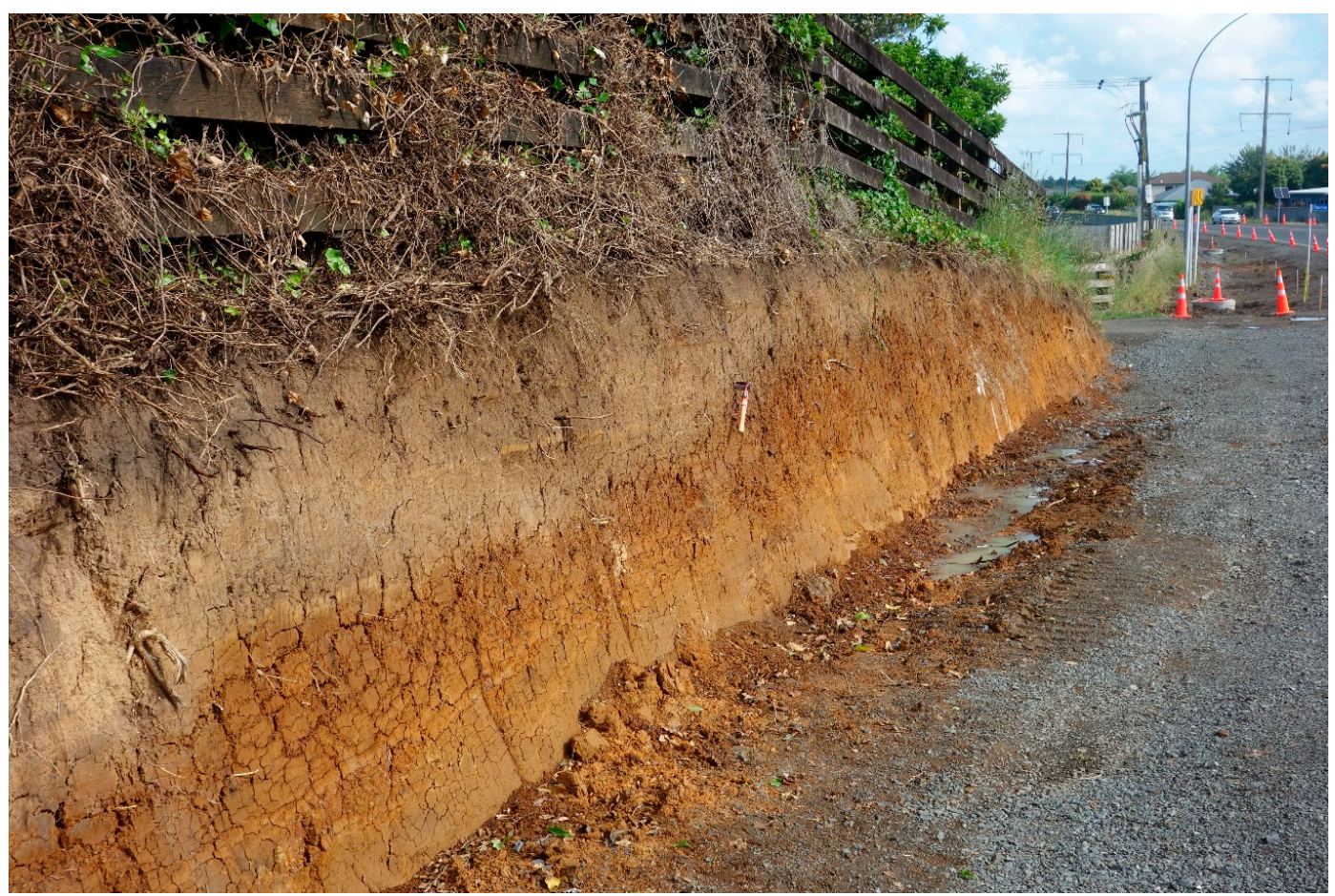

Figure 2. Exposure of Kainui silt loam on Gordonton Road practically opposite the intersection with Thomas Road ( $37^{\circ} 43^{\prime} 55^{\prime \prime}$ S, $175^{\circ} 17^{\prime} 15^{\prime \prime}$ E), northern Hamilton (Figure 1). The two-storeyed nature of the Kainui soil is striking, with the pale composite coverbed of late Quaternary tephras contrasting with the paleo-surface of the underlying dark reddish-brown clay-rich Hamilton Ash beds. The profile looks a lot like the 'strong texture-contrast' or 'duplex' soils that are common in Australia, e.g., [40,41] and elsewhere but it has quite different origins. The wavy to irregular boundary (marked by the small cutting tool c. $30 \mathrm{~cm}$ long) likely reflects tree-overturn hollows and mounds [42] (cf. [43]) (Figure 3). The thickness of the coverbed here-each part of which has been an ' $\mathrm{A}$ ' horizon at the land surface at some time since c. $50 \mathrm{ka}$-ranges from a maximum of c. $0.7 \mathrm{~m}$ (foreground) to c. $0.3 \mathrm{~m}$. Photo: D.J. Lowe.

This 'two-storeyed' character, but one of many special features associated with the Kainui soil, provides a critical starting point, namely that soil stratigraphy and tephrochronology are central to understanding the soil's genesis, nature and age. Therefore, after an introduction about the occurrence and nomenclature of the Kainui soil, I firstly review its key morphological and compositional features, and describe its origins via upbuilding pedogenesis, using a soil stratigraphic approach centred on tephrostratigraphy. Tephrostatigraphy is the study of sequences of tephra layers and associated deposits, their distribution and stratigraphic relationships and their relative and numerical ages; the discipline involves defining, describing, characterizing and dating tephra layers in the field and laboratory [10]. Emphasis in this section is on the coverbed of multiple younger tephras making up the upper profile and the associated clay mineralogy. Taxonomy is covered next. I then describe how new morphological observations of the soil's upper profile (the pedogenically altered coverbed of younger tephras) help to explain its genesis through understanding the soil horizonation. Finally, I discuss the older, strongly weathered tephras making up the Kainui soil's lower profile. Earlier beds and paleosols underlying the lower profile are touched upon as well. Essentially a buried paleosol comprising relict clay-illuvial argillic and kandic horizons (containing clay films or cutans/argillans), the origins of this lower part of the Kainui soil remain somewhat problematic because of masking by strong weathering and soil welding (the merging of one solum with another back through time). Together the observations and conclusions, which rely on the synthesis of a wide range of literature as well as original observations, should provide, I trust, insight of value potentially to Quaternary pedologists, paleopedologists, tephrochronologists, and mineralogists who are interested in tephra-derived soils 
(especially Ultisols and Andisols) and paleosols and their genesis, soil stratigraphy, upbuilding pedogenesis, clay mineralogy, and in traditional soil morphological description and classification.

\subsection{Note on the Definition of 'Soil,' Soil Horizon Nomenclature, and Classification}

I use the term 'soil' to mean a natural, four-dimensional body (comprising three-dimensional pedons together with the fourth dimension of time) typically c. 1 to $2 \mathrm{~m}$ thick mantling the land surface that can support rooted plants and which are characterized by one or more soil horizons that have evolved through additions, losses, transfers, and transformations of energy and matter by interactions of climate, biota, relief, and parent materials through time [1,44,45]. For taxonomic purposes, the lower boundary of a soil profile or pedon is set at $1 \mathrm{~m}$ in NZSC [11] and $2 \mathrm{~m}$ in ST [1]. The soil horizonation nomenclature used in the article is based on [46], although I refer also to the (similar) system used in ST [34,47]. Soil classifications are reported for both NZSC and ST [11,34].

\section{Kainui Soil and its Distribution in the Central and Northern Waikato Region}

At lower taxonomic levels, the Kainui soil has two closely similar identities: as a soil type defined within the Kainui series [48-51] and as a sibling defined within the Kainui family [52]. The latter identity is used as a mapping unit in S-map, a digital (online) soil map database [53] that has been developed by Manaaki Whenua Landcare Research (a New Zealand Government-funded soil-ecosystem research organisation) in recent years.

The upper horizons of the Kainui soil (in coverbed materials) are texturally silt loams, typically with c. $20 \%$ sand $(0.06-2.0 \mathrm{~mm})$, c. $50 \%$ silt $(2-60 \mu \mathrm{m})$ and c. $30 \%$ clay $(<2 \mu \mathrm{m})$ in the fine-earth fractions; (dry) bulk densities average c. $1.2 \mathrm{~T} / \mathrm{m}^{3}$. In contrast, the lower horizons (weathered Hamilton Ash) are clay loams to clays, with c. $3 \%$ sand, c. $12 \%$ silt and c. $85 \%$ clay on average; bulk densities are c. 1.4-1.5 T/ $\mathrm{m}^{3}$. The bulk densities reflect the dominance of halloysitic clays (described below) [54]. Other physical and chemical properties for the Kainui soil are reported elsewhere [18,35,49-51,55].

The Kainui soil is distributed widely in the northern Hamilton lowlands including the Waikato District, Matamata-Piako District, and the Hauraki lowlands (Figure 1) [53]. It occurs on the summits, shoulders and upper- and middle-backslopes of low rolling hills, and old terraces, that are underlain in many places, generally, by old pyroclastic flow deposits (ignimbrites) and reworked derivatives (c. 1.2-0.9 Ma) [56-58]. In turn, these deposits are capped with strongly weathered tephra-fall deposits including Kauroa Ash beds (c. $0.8 \mathrm{Ma}$ ), Hamilton Ash beds (c. $340 \mathrm{ka}$ to >c. $50 \mathrm{ka}$ ) and finally a thin coverbed ( $\leq$ c. $50 \mathrm{ka}$ ) (Figure 3) $[57,59,60]$. The hills are old, Mid-Quaternary landforms. They represent a paleo-topography that was formed before c. $340 \mathrm{ka}$ on the tephrochronological basis that the Rangitawa Tephra (aged c. $340 \mathrm{ka}$, see below) drapes over sloping erosional geomorphic surfaces that cut across antecedent horizontal to subhorizontal deposits and paleosols $>0.78 \mathrm{Ma}$ in age (Figure 3). 


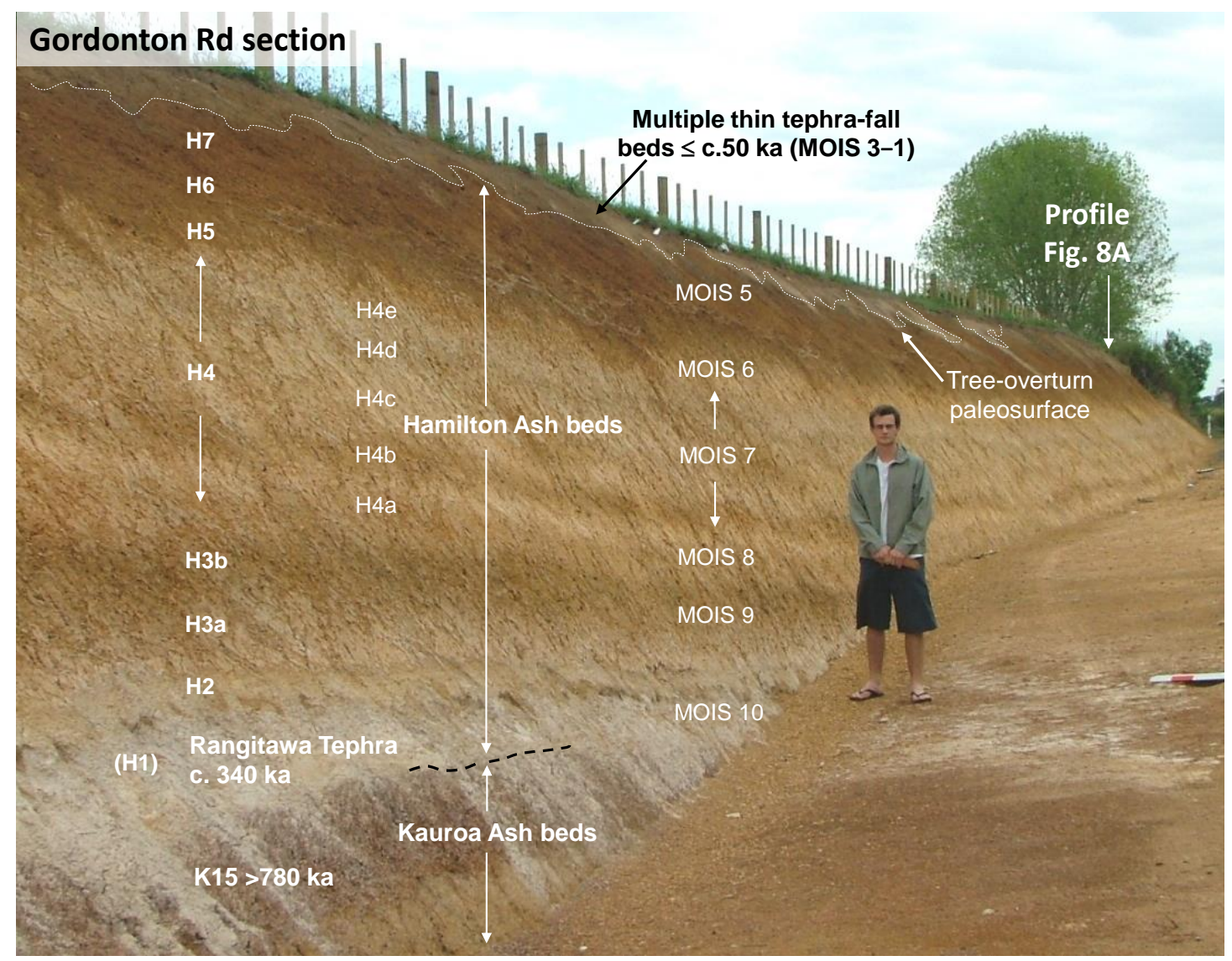

Figure 3. A long section of weathered tephras, including the Hamilton Ash $(\mathrm{H})$ beds (designations follow [61]), exposed in a road cut on Gordonton Road ( $37^{\circ} 42^{\prime} 21^{\prime \prime} \mathrm{S}, 175^{\circ} 18^{\prime} 14^{\prime \prime} \mathrm{E}$ ) about $3 \mathrm{~km}$ north of Hamilton (Figure 1). The dark reddish-brown soil horizons on uppermost Hamilton Ash (H6/7) probably reflect pedogenesis in the Last Interglacial or Marine Oxygen Isotope Stage (MOIS) 5e [55], a New Zealand equivalent of the Sangamon paleosol/geosol of North America (e.g., [24,62,63]). Above the unconformable boundary (marked by the upper dashed line) is a thin (c. $0.6 \mathrm{~m}$ on average but quite variable), silty coverbed of multiple, intermixed late Quaternary tephras that have accumulated incrementally over the past c. $50 \mathrm{ka}$. The undifferentiated coverbed mélange is occasionally overthickened in tree-overturn hollows up to c. 1.0-1.2 m deep. In such deep hollows (>c. $0.8 \mathrm{~m}$ in depth), upper profiles sporadically can be mainly allophanic rather than halloysitic [18]. The entire sequence of weathered Hamilton Ash beds may be considered as a c. 200,000-year-old composite, welded paleosol. Near the base of the section is Rangitawa Tephra (also known as bed $\mathrm{H1}$ ), aged c. $340 \mathrm{ka}$. It overlies unconformably a remnant of a remarkably ancient paleo-surface represented by a buried, extremely clay-rich soil on bed K15, or Waiterimu Ash, of the Kauroa Ash sequence $[55,61,64-68]$. K15 is aged >c. $780 \mathrm{ka}$ on the basis of its reversed magnetic polarity $[55,65,69]$. It predates the Matuyama-Bruhnes boundary, which is dated at c. $783 \mathrm{ka}$ [70]. The unconformity therefore represents at least c. 450,000 years. Even older Kauroa beds (not visible in photo) extend below the section. At other locations in western Waikato the Kauroa Ash beds date back to c. 2.3 Ma [65,71,72]. Photo: D.J. Lowe.

The Kainui soil is used extensively for agriculture including livestock (such as dairying) and cropping (mainly maize) as well as horticulture including market gardening and, uniquely in New Zealand, tea (Figure 4). 


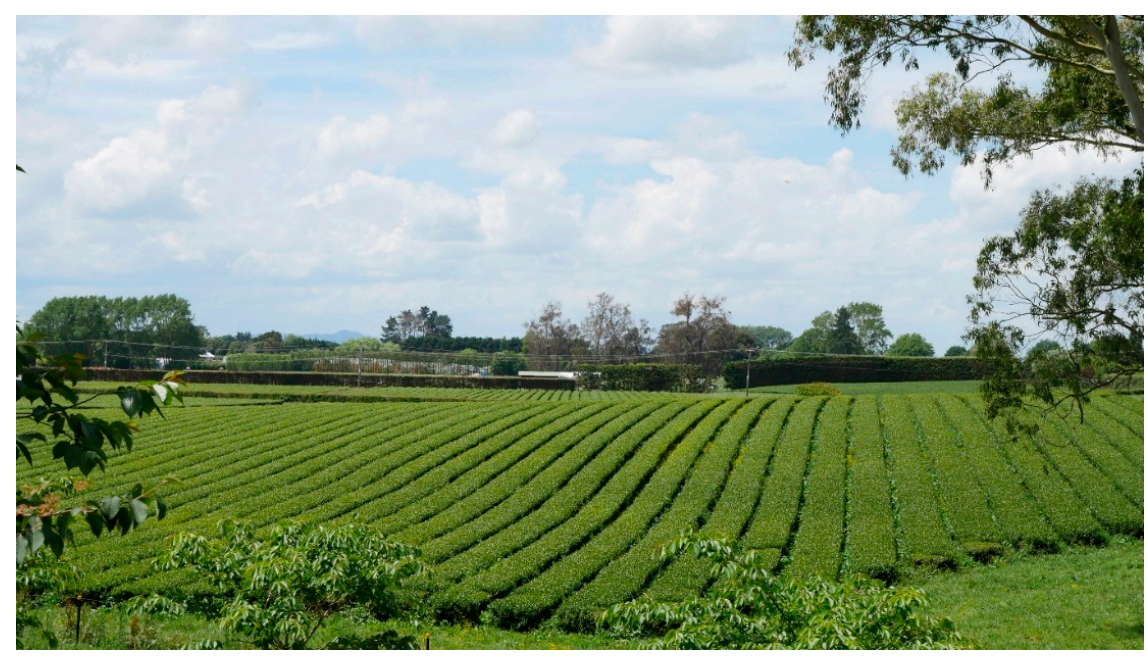

Figure 4. Tea (Camellia sinensis) growing well on Kainui soils (Kandiudults) at the Zealong Tea Estate almost directly across the road from the Gordonton Road section (Figures 1 and 3). Some of the Kainui soil's physical properties and some climatic conditions, however, are towards the limits for commercial tea, which typically requires light (coarser-textured), friable soils and good drainage. The silt-rich coverbed, its moderate drainage, and its marginal thermic soil temperature regime, seem to meet the needs. Although the soil moisture regime is udic, both drought and frost can occur [73] and tea can be susceptible to these conditions. The perching of water on the buried paleosol, giving rise to saturation possibly for several days or near saturated conditions for several months (see text), is evidently able to be tolerated. A favourable feature for tea is the moderately to strongly acid subsoil in the upper Kainui soils [35,51,55]. Photo: S.J. Lowe.

\section{Origin of the Kainui Soil}

\subsection{Soil Stratigraphy (Including Tephra Identification) and Upbuilding Pedogenesis}

The Kainui soil, as noted already, is best described as a two-storeyed soil, the upper storey c. 0.4 to $0.7 \mathrm{~m}$ thick comprising a composite coverbed of multiple, intermixed thin tephra layers deposited incrementally since c. $50 \mathrm{ka}$ (commonly denoted 'late Quaternary') overlying a buried paleosol on older, strongly weathered clayey Hamilton Ash beds. The profile, extending over one metre in depth, thus encompasses two main 'units' that are easily seen when the profile is dry because of the contrasting colours and textures (Figure 2). An earlier interpretation that the coverbed comprises loess has been discounted partly because the primary mineralogy is pyroclastic in origin (although the clay minerals did not seem to 'fit' that origin, as discussed below) and because 22- to 20-ka-aged lakes adjacent to the hills on which Kainui soils occur in the northern Hamilton lowlands (Figure 1) contain in their organic-rich sediments numerous thin but well-preserved rhyolitic (silica-rich, $\geq \mathrm{c}$. $70 \mathrm{wt} \% \mathrm{SiO}_{2}$ ) and andesitic (moderately high silica content, c. 60-70 wt\% $\mathrm{SiO}_{2}$ ) tephra-fall layers derived from five volcanic centres: Okataina, Taupō, Tuhua, Tongariro, and Egmont (Figure 1B) $[18,36,59,74,75]$. As illustrated in Figure 5, these lacustrine deposits therefore provided an integrated dossier of multitudinous macroscopic (visible) tephras (c. 40 in total, based on [36]) that have fallen on the land surface since c. $22 \mathrm{ka}$, the oldest being Okareka Tephra aged c. $21.8 \mathrm{ka}$, which is preserved in Lake Rotomanuka $[36,76]$. The youngest is the faintest of dustings of fine ash deposited during the 1995-1996 eruptions of Mt Ruapehu [77,78]. The tephras are thin, mostly a few millimetres to centimetres in thickness. Work currently in progress is re-examining newly acquired lake sediment cores to detect and identify submillimetre tephra deposits [79], now referred to as cryptotephras ('hidden' glass shard concentrations insufficiently numerous to be visible as a layer to the naked eye) $[10,26]$.

Three older, pre-Okareka, tephras have been preserved in an unweathered state in a series of cores that extended into pre-lake colluvial deposits beneath the lake sediments at Lake Maroroto (Figure 1) [18,75]: (i) Okaia Tephra, c. 28.6 ka [76]; (ii) Tāhuna Tephra, c. 39.3 ka [75,80-82]; and 
(iii) Rotoehu Ash, c. 50 ka [83-86] (Figure 5). The correlation (identification) of these older tephras in the lower Maratoto cores was made using their diagnostic ferromagnesian mineral assemblages together with glass-shard major element compositions and stratigraphic superpositions (Figures 5 and 6, Table 1). The Okaia Tephra has not previously been reported in the Hamilton Basin. The fact that this tephra, rhyolitic in character, lies stratigraphically beneath sediments dated at c. $20 \mathrm{ka}$ and above the Rotoehu Ash (dealt with below) dated at c. $50 \mathrm{ka}$, narrows the options for its correlation to a tephra of either the Taupō-derived Okaia Subgroup or the Okataina-derived Mangaone Subgroup [87], which were deposited between c. $50 \mathrm{ka}$ and c. 25 ka [30,81,83,88].

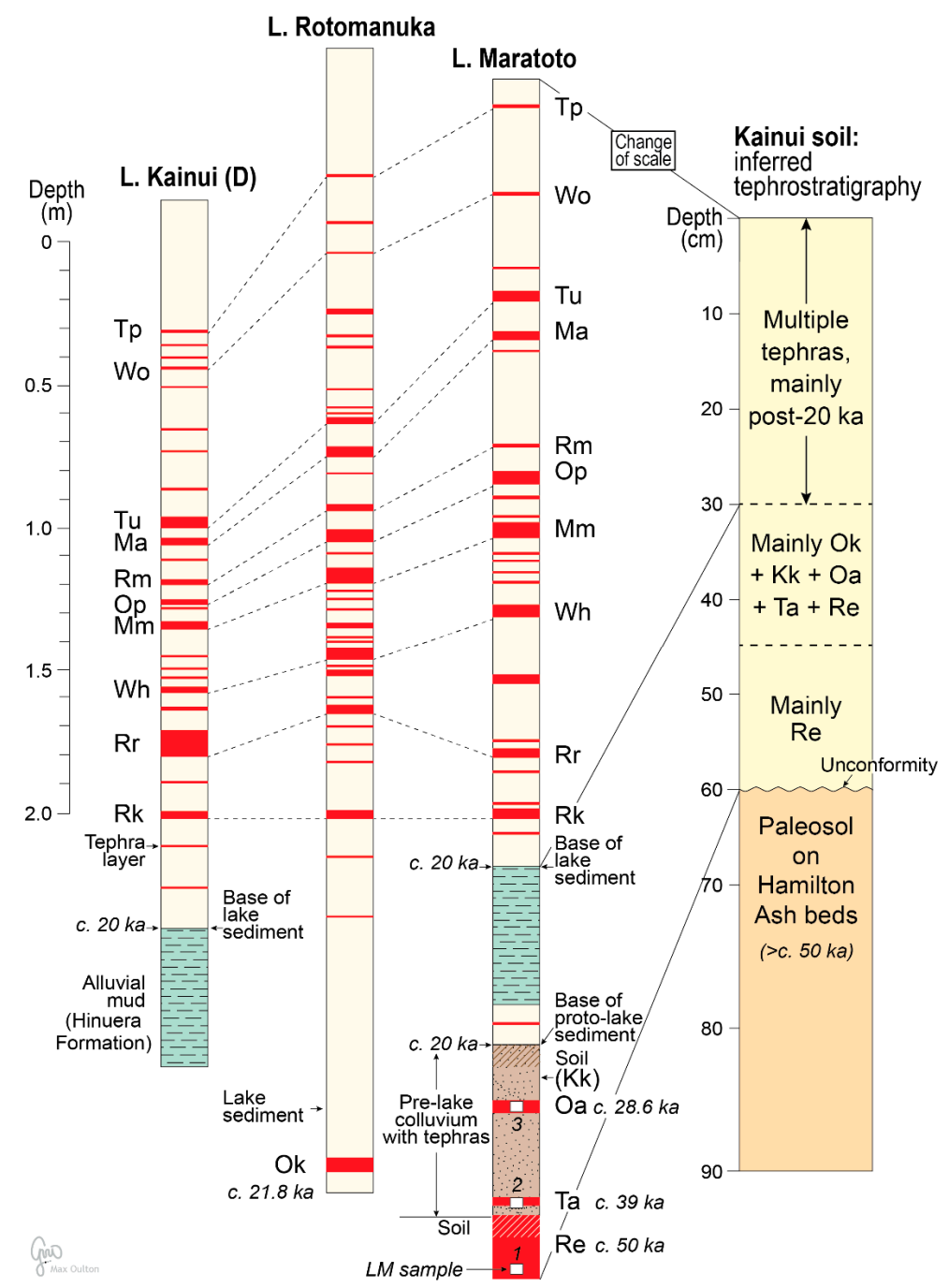

Figure 5. Stratigraphy and correlation of tephra layers in lake sediment cores from lakes Kainui (also known as Lake D), Rotomanuka and Maratoto and underlying pre-lake lithologies and soil horizons (after [36] p. 130-131 and [75] p. 687). Dates (calibrated) on lowermost lake sediments are after $[36,75,89]$. Named tephras and their approximate calendrical ages, based on $[36,76,90,91]$ are as follows: Tp, Taupō (1.7 ka or $232 \pm 10 \mathrm{CE}$ ); Wo, Whakaipo (2.8 ka); Tu, Tuhua (7.5 ka); Ma, Mamaku (8.0 ka); Rm, Rotoma (9.4 ka); Op, Opepe (10.0 ka); Mm, Mangamate (11.3 ka); Wh, Waiohau (14.0 ka); Rotorua (15.6 ka); Rk, Rerewhakaaitu (17.6 ka); Ok, Okareka (21.8 ka); and Kk, Kawakawa (25.4 ka) (not visible as layer). In the lower Lake Maratoto core (core number 4,1i in Reference [75] p. 687), the older tephras (ages shown) are Oa, Okaia; Ta, Tāhuna; and Re, Rotoehu. The two buried soil horizons (formed when the deposits were at the land surface) represent disconformities. The column at right depicts the inferred stratigraphy of the Kainui soil. The boundaries of the coverbed tephrostratigraphy are notional because of continuous tephra intermixing (see text). 
Figure 5 shows that the parent materials of the Kainui soil (to c. $1 \mathrm{~m}$ depth) are diachronous (time-transgressive), spanning an age range that could be as much as c. 125,000 years if the upper Hamilton Ash (which is undated) is as old as c. $125 \mathrm{ka}$ in age (MOIS 5e). To convey the soil's two-storeyed, upbuilding-derived, diachronous character, the parent materials may be described, for example, as 'a composite of multiple tephras younger than c. 50 ka over strongly weathered tephra considerably older than c. 50 ka' or as 'a composite of late Quaternary tephras on a buried paleosol on older tephras (Hamilton Ash)'.

Although the proportions of ferromagnesian minerals in tephras can vary from sample to sample to quite some degree, e.g., [10,81,92], and on their own may not necessarily be definitive [10], the abundance of augite, together with hypersthene and calcic hornblende in sample LM3, and the close similarity of the major element composition of the constituent glass to that of reference glass from Okaia Tephra (Table 1), confirms its identification as the Taupō-volcano derived Okaia Tephra [93]. In turn, the Tāhuna Tephra beneath Okaia Tephra is similarly constrained chronostratigraphically, being older than c. $28.6 \mathrm{ka}$ (the age for Okaia Tephra) and younger than c. $50 \mathrm{ka}$ (Rotoehu Ash). The ferromagnesian mineralogy of sample LM2 comprises hornblende and hypersthene, with no augite, consistent with published analyses for Tāhuna Tephra (Figure 6A,B) [80]. As well, the abundances of most of the major elements (as oxides) of glass shards from LM2 closely match those for glass from this tephra as reported in the literature (Table 1). The identification of Tāhuna Tephra (derived from Taupō volcano) [80] in the Hamilton Basin was reported previously by [75] but misidentified by [18], herewith corrected.

The confirmed deposition in the central Hamilton lowlands of the Okaia and Tāhuna tephras, together amounting to c. $10 \mathrm{~cm}$ in thickness or more, along with Rotoehu Ash (see below), thus helps to complete a more comprehensive picture of the tephra-fall origins of the entire coverbed that mantles the low hills (Figure 5). Kawakawa Tephra (also known as Oruanui or Kawakawa-Oruanui tephra, KOT), aged c. 25.4 ka $[90,94]$, is additionally known to have been deposited in the region (on the basis of field observations and geochemical fingerprinting $[18,35,75,95,96])$. (Potentially, further tephras, as yet unidentified, may also occur.)

Mineralogical and geochemical 'fingerprinting' of the coverbed deposits of the Kainui soil itself, using ferromagnesian mineral assemblages together with major-element compositional analyses of individual glass shards, primary minerals and Fe-Ti oxides, and bulk analyses of Fe-Ti oxides [18,35], although constrained because of the admixed nature of the altered coverbed materials, support the tephra correlations inferred from the detailed tephrostratigraphy of the adjacent lacustrine sequences [18,35,36]. For example, the Tuhua Tephra (aged $7.5 \mathrm{ka}$ ) [91], derived from Mayor Island (Tuhua volcano) [83], has a unique mineralogy (including abundant aegirine, a clinopyroxene, in the ferromagnesian mineral assemblage) and volcanic glass of peralkaline composition [37,83,92,97]. These distinctive compositional attributes, including aegirine in small quantities (c. $1-4 \%$ of the ferromagnesian mineral assemblage), have been identified in samples from the coverbed at Rototuna Road [18,35] (Figures 1 and 6). In the field, topsoils ('A' horizons) of the Kainui soil contain ubiquitous but sparse fine pumice lapilli, which are remnants from fallout from the Taupō eruption of $232 \pm 10$ CE $[36,98,99]$. 

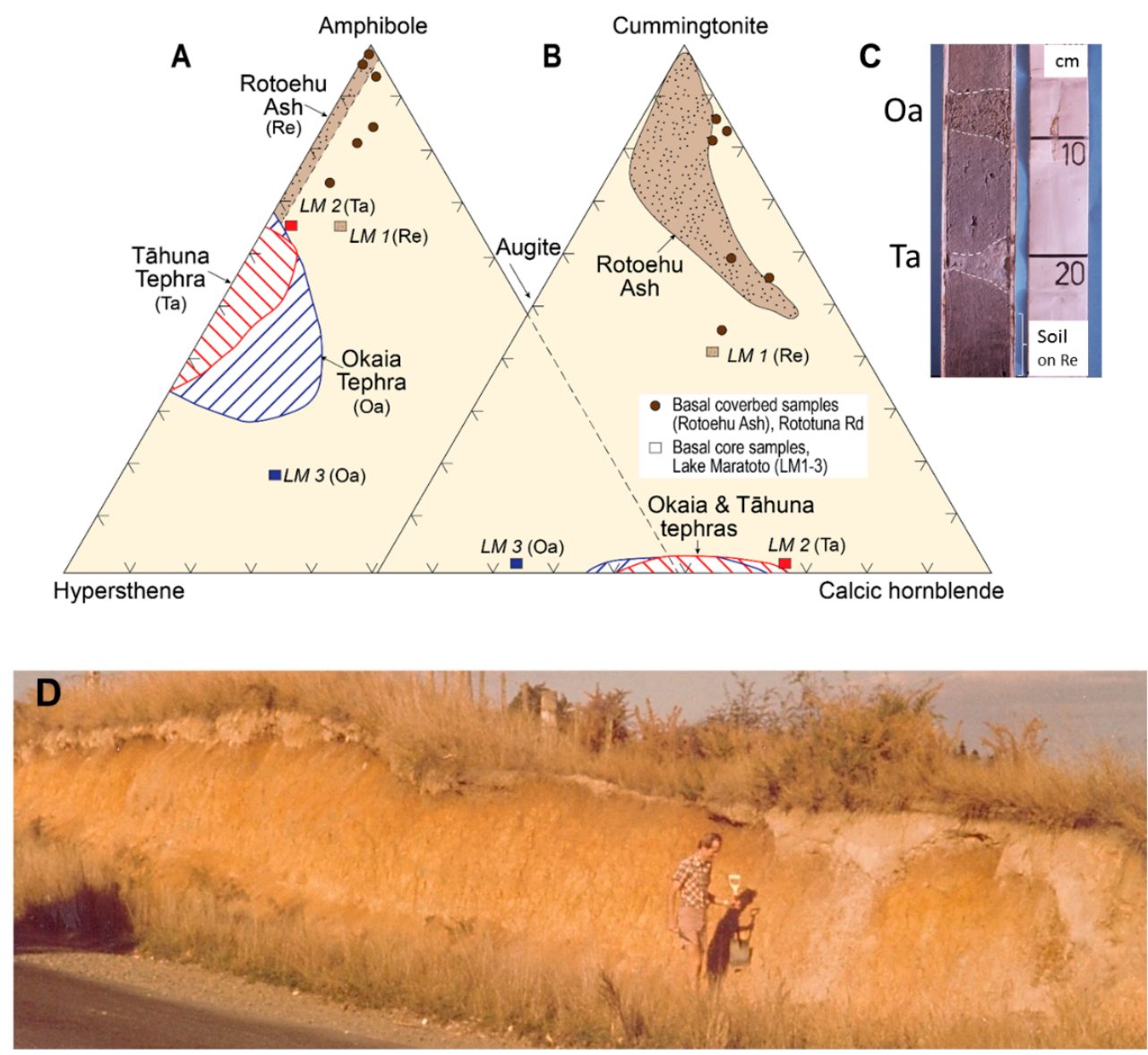

Figure 6. Ternary diagrams (A and B) showing relative abundances of ferromagnesian silicate minerals in compositional 'fields' (based on analyses of samples from known reference sites, see below) and comparison with analyses of samples from the coverbed (at Rototuna Road) and basal core samples, Lake Maratoto, showing their general similarity. (A) Amphibole (mainly calcic hornblende and cummingtonite), augite (clinopyroxene) and hypersthene (orthopyroxene). Data sources: Rotoehu Ash [18] (p. 298), [35] (p. 111, 383), [75] (p. 685-686), [93] (p. 69), [100] (p. 349), [101] (p. 2053); [102] (p. 349); Tāhuna Tephra [93] (p. 69), [100] (p. 349); Okaia Tephra [93] (p. 69); basal coverbed samples, Rototuna Road [35] (p. 111, 383), [18] (p. 294); basal core samples LM1-3, Lake Maratoto [75] (p. 685-686). (B) Cummingtonite, hypersthene (orthopyroxene) and calcic hornblende. Data sources as for (A). (C) Photograph of 30-cm-long part of a core from beneath Lake Maratoto (core number 4,1f in Reference [75] p. 687). It shows pumiceous Okaia (Oa) and Tāhuna (Ta) tephras preserved as c. 5-cm-thick layers in pale (reduced) brownish-grey muds inferred to be pre-lake colluvial deposits (mainly reworked Okaia and Tāhuna tephras). These deposits overlie a weakly developed greyish-brown soil horizon on Rotoehu Ash (Figure 5). Photo: D.J. Lowe. (D) Road cut exposing the coverbed overlying the paleosol on Hamilton Ash at Rototuna Road at c. $39 \mathrm{~m}$ above sea level (asl) in Hamilton (Figure 1), very near the intersection with Cate Road $\left(37^{\circ} 44^{\prime} 03^{\prime \prime}\right.$ S, $\left.175^{\circ} 16^{\prime} 05^{\prime \prime} \mathrm{E}\right)$. The exceptionally dry conditions have allowed (almost pure) Rotoehu Ash to stand out as a distinct white layer c. $0.2 \mathrm{~m}$-thick at the base of the coverbed in the two paleo-hollows to the right of the person. The white ash material, being slightly less weathered and hence less (weakly) cemented and less coherent, has broken away somewhat from the face of the section and some of it has fallen or washed down over the reddish-brown surface of the Hamilton Ash beds beneath the deep hollows. The Rotoehu Ash could have been somewhat overthickened to c. $0.3 \mathrm{~m}$ thickness in the deepest hollow (with steepened sides) soon after deposition. The five basal coverbed samples analysed mineralogically and plotted in the ternary diagrams A and B were collected from basal deposits in three locations at this site including at c. $1.1 \mathrm{~m}$ depth in the deepest hollow at far right (after [35] pp. 39 and 42). Photo: D.J. Lowe. 
Table 1. Major element compositions ${ }^{a}$ of glass shards of Okaia and Tāhuna tephras.

\begin{tabular}{|c|c|c|c|c|c|c|}
\hline \multirow[b]{2}{*}{$\begin{array}{l}\text { Oxide or } \\
\text { Element }\end{array}$} & \multicolumn{3}{|c|}{ Okaia Tephra } & \multicolumn{3}{|c|}{ Tāhuna Tephra } \\
\hline & $\begin{array}{l}\text { L. Maratoto } \\
\text { (Sample LM3, } \\
\text { Figure 5) }\end{array}$ & $\begin{array}{c}\text { Scott Rd } \\
\text { Reference Site } \\
\text { No. } 588^{\mathrm{e}}\end{array}$ & $\begin{array}{l}\text { Reference } \\
\text { Site }^{\mathrm{f}}\end{array}$ & $\begin{array}{l}\text { L. Maratoto } \\
\text { (Sample LM2, } \\
\text { Figure 5) }\end{array}$ & $\begin{array}{l}\text { Reference Sites } \\
\text { (Compilation) } g\end{array}$ & $\begin{array}{c}\text { Scott Rd } \\
\text { Reference Site } \\
\text { No. } 587^{\mathrm{h}}\end{array}$ \\
\hline \multirow{2}{*}{$\mathrm{SiO}_{2}$} & 77.87 & 77.57 & 77.50 & 78.38 & 77.60 & 77.56 \\
\hline & (0.99) & $(0.21)$ & $(0.34)$ & $(0.24)$ & $(0.21)$ & $(0.18)$ \\
\hline $\mathrm{Al}_{2} \mathrm{O}_{3}$ & 12.26 & 12.55 & 12.42 & 12.36 & 12.29 & 12.57 \\
\hline $\mathrm{TiO}_{2}$ & $(0.05)$ & $(0.07)$ & $(0.06)$ & $(0.03)$ & $(0.07)$ & $(0.05)$ \\
\hline \multirow{2}{*}{$\mathrm{FeO}_{\mathrm{t}}{ }^{\mathrm{c}}$} & 1.25 & 1.31 & 1.29 & 1.09 & 1.10 & 1.04 \\
\hline & $(0.28)$ & $(0.08)$ & $(0.10)$ & $(0.08)$ & $(0.09)$ & $(0.09)$ \\
\hline \multirow{2}{*}{$\mathrm{MnO}$} & & 0.06 & 0.04 & & 0.07 & 0.07 \\
\hline & na & (0.03) & $(0.04)$ & na & $(0.04)$ & $(0.04)$ \\
\hline \multirow{2}{*}{$\mathrm{Na}_{2} \mathrm{O}$} & 3.54 & 3.81 & 3.90 & 3.35 & 3.48 & 3.56 \\
\hline & $(0.29)$ & $(0.13)$ & $(0.14)$ & $(0.21)$ & $(0.16)$ & $(0.11)$ \\
\hline \multirow{2}{*}{$\mathrm{K}_{2} \mathrm{O}$} & 3.56 & 3.29 & 3.28 & 3.29 & 4.09 & 4.01 \\
\hline & $(0.74)$ & $(0.11)$ & $(0.10)$ & $(0.29)$ & $(0.10)$ & $(0.05)$ \\
\hline \multirow{2}{*}{$\mathrm{Cl}$} & 0.12 & 0.20 & 0.19 & 0.12 & 0.14 & 0.19 \\
\hline & $(0.05)$ & $(0.02)$ & $(0.02)$ & $(0.02)$ & $(0.03)$ & $(0.02)$ \\
\hline \multirow{2}{*}{$\mathrm{H}_{2} \mathrm{O}^{\mathrm{d}}$} & 3.07 & 7.70 & 5.99 & 2.37 & 5.36 & 4.02 \\
\hline & $(2.10)$ & (1.89) & $(2.36)$ & (1.98) & $(1.61)$ & $(1.79)$ \\
\hline$n$ & 18 & 10 & 10 & 12 & 41 & 11 \\
\hline
\end{tabular}

a Analyses are all reported as mean values (standard deviations in parentheses) of $n$ shards on a normalised 100-\%-loss-free basis (following international practice [26]); na, not analysed. ${ }^{b}$ Analyses were obtained on glass shards in the $0.0625-0.25 \mathrm{~mm}(2-4 \varphi)$ size fraction using a JEOL JXA-733 Superprobe at the Analytical Facility, Victoria University of Wellington, with $8.0 \mathrm{nA}$ beam current, $10 \mu \mathrm{m}$ beam diameter and peak counts of $3 \times 10 \mathrm{~s}$ (meaned) and with Na analysed first [103,104]. Smithsonian microbeam glass standards VG-568 and VG-99 [105] and other reference samples including KN-18 [104] were used to correct for instrumental drift. Analysts were D.J. Lowe (LM2) and P.C. Froggatt (LM3). Some minor loss of $\mathrm{Na}$ and $\mathrm{K}$ through volatilisation is likely (the $\mathrm{K}_{2} \mathrm{O}$ values for LM2 are markedly low; concomitantly, $\mathrm{SiO}_{2}$ content is probably overestimated) but $\mathrm{FeO}_{\mathrm{t}}$ and $\mathrm{CaO}$ values, which are especially useful for glass composition-based tephra correlation studies in New Zealand, e.g., [39,106,107], and most other oxides, are a good match to those of the reference samples when evaluated in conjunction with stratigraphic position and ferromagnesian mineralogical assemblages associated with Okaia and Tăhuna tephras (Figures 5 and 6). Source: unpublished data of D.J. Lowe (acquired in 1984). ${ }^{c}$ Total Fe reported as FeO. ${ }^{d}$ Difference

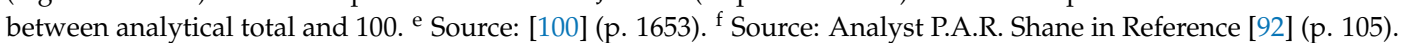
g Source: [81] (p. 387). ${ }^{\text {h }}$ Source: [80] (p. 104) and [100] (p. 1653).

The basal age (c. $50 \mathrm{ka}$ ) of the coverbed part of the Kainui soil stems from the predominance of Rotoehu Ash in the lowermost deposits. This correlation is therefore a critical one in the soil stratigraphy. I have used its distinctive ferromagnesian mineralogical assemblage to secure the correlation unequivocally. Rotoehu Ash is one of only three rhyolitic tephras $\leq 50 \mathrm{ka}$ in North Island that are dominated by the marker mineral, cummingtonite, a pale-green amphibole $[81,83,92]$. The others, Rotoma and Whakatane tephras, Holocene in age, are also present but the lake sediment records in the Hamilton lowlands show that Rotoma tephra is $\leq$ c. $5 \mathrm{~mm}$ thick and Whakatane Tephra is 'microscopic' (i.e., submillimetre in thickness) (Figure 5) [36,37]. Hence their potential contribution of cummingtonite to the coverbed mineral assemblages would be very minor (effectively negligible). In contrast, the cummingtonite-rich basal materials representing Rotoehu Ash in pre-lake deposits at Lake Maratoto (underlying the c. 39-ka Tāhuna Tephra) are c. $30 \mathrm{~cm}$ thick on average ([75] p. 687). The sample of Rotoehu Ash from these pre-lake materials at Lake Maratoto (sample LM1) is dominated by cummingtonite (Figure 6), matching the similarly high relative abundances of this mineral in five samples from the basal few centimetres of the coverbed deposit at Rototuna Road, thereby confirming correlation with the widespread Rotoehu Ash.

From mapping in the region and measurements of the relative proportions of cummingtonite in ferromagnesian mineral fractions, I estimated the thickness of Rotoehu Ash in the northern Hamilton area to be c. $25 \pm 10 \mathrm{~cm}$ [35], broadly consistent with isopach maps for Rotoehu Ash deposits in 
adjacent regions $[85,95,108]$, and with the thicknesses of c. $30 \mathrm{~cm}$ evident in cores from Lake Maratoto to the south [75].

Although the base of the coverbed is dominated by quasi-pure Rotoehu Ash (the ash can sometimes be recognised in the field as a white, c. $0.2 \mathrm{~m}$-thick, intermittent layer, as evident in Figure $6 \mathrm{D}$ ), the content of cummingtonite generally decreases upwards through the coverbed, with abundances in the ferromagnesian mineral assemblage ranging from c. $15 \%$ to $80 \%$ [18,35], indicating that subsequent tephra deposition has progressively 'diluted' the Rotoehu Ash materials towards the soil surface. That crystals of aegirine, originating exclusively from the mid-Holocene deposition of the Mayor Island-derived Tuhua Tephra (aged c. $7.5 \mathrm{ka}$ ), occur intermixed with the copious cummingtonite crystals derived almost wholly from Rotoehu Ash (aged c. $50 \mathrm{ka}$ ) throughout the coverbed [35] is entirely consistent with the genesis of the Kainui soil by upbuilding pedogenesis, as discussed next, and emphasises the importance of pedoturbation in particular $[18,35,97]$.

One of the biggest advances in understanding since 1991, when I wrote that the thin multiple tephra layers in the upper Kainui soil had been "weathered and blended by soil forming processes," thereby masking their origin [109], is the recognition that these profile features reflect upbuilding pedogenesis. Upbuilding pedogenesis is the ongoing formation of soil via top-down processes whilst tephras or loess (or alluvium, colluvium) are concomitantly added to the land/soil surface as normal geological processes [19,110-114]. Muhs et al. [115] promoted the core concept nicely through the title of their paper (in part), "Holocene loess deposition and soil formation as competing processes." These concepts have been documented and interpreted in other (notably prescient) research, much of it micromorphological, on loess-paleosol sequences in China, USA, and western Europe, e.g., [27,116118]. At locations proximal to volcanic sources in North Island, resultant soils may show distinctive layering, along with buried horizons or paleosols, forming multi-layered profiles. Such profiles are evident in many road cuttings near the central TVZ (Figure 1), e.g., $[28,119,120]$. Paleosols with stratigraphic significance may be called geosols (pedostratigraphic units) in the North American Stratigraphic Code [25,121,122].

The frequency and thickness of tephra accumulation (and other factors) determine how much impact top- down soil-forming processes have on the ensuing profile character and if either developmental or retardant upbuilding, or both, prevail. 'Top-down' pedogenesis comprises multiple processes operating mainly from the land surface, driven by the organic and water cycles [123], that result in the gradual deepening of the profile as a downward moving front on a pre-existing parent material. That is, 'classical' soil formation (as described in most soil science textbooks) proceeds by effectively modifying the pre-existing static parent material(s) to a greater or lesser extent according to a range of factors that dictate an ensemble of soil processes (e.g., [2,3]). The term 'top-down pedogenesis' was coined by Almond and Tonkin [124] (see also [118]).

In contrast, the terms 'developmental' and 'retardant' upbuilding pedogenesis were invented by Johnson and Watson-Stegner [125] and Johnson et al. [126,127] as part of their dynamic-rate model of soil evolution whereby soils are envisaged to evolve by 'ebb and flow' through time [24]. Retardant upbuilding occurs when a relatively thick layer of tephra (or alluvium or colluvium) is instantaneously added to the surface or where the rate of accumulation of many thin deposits is so fast that the original soil is rapidly buried (overwhelmed) and thus becomes a buried horizon, isolated and cut-off from the new land surface in which top-down pedogenesis begins anew (Figure 7). Developmental upbuilding, illustrated superbly by the tephra-derived Kainui soil (Figure 8A), occurs when the rate of addition of tephra or loess to the land is incremental (accretionary) and at a rate sufficiently slow to enable top-down pedogenesis to keep pace as the land gradually rises [27,116,117,127]. At Gordonton Road, the rate of accumulation of tephras in the upper profile (Figure 8A) averages only c. $1 \mathrm{~mm}$ per century, about the same rate (for example) as very slow loess accumulation on the West Coast, South Island $[113,128,129]$. (Mass flux as well as accretion rates can be calculated by incorporating bulk density estimates, for example References $[128,130]$.) The slow accumulation of the distal tephras in 
the central Waikato region has effectively mimicked continuous loess accretion but without 'switching off' during glacial or stadial periods [113,130].
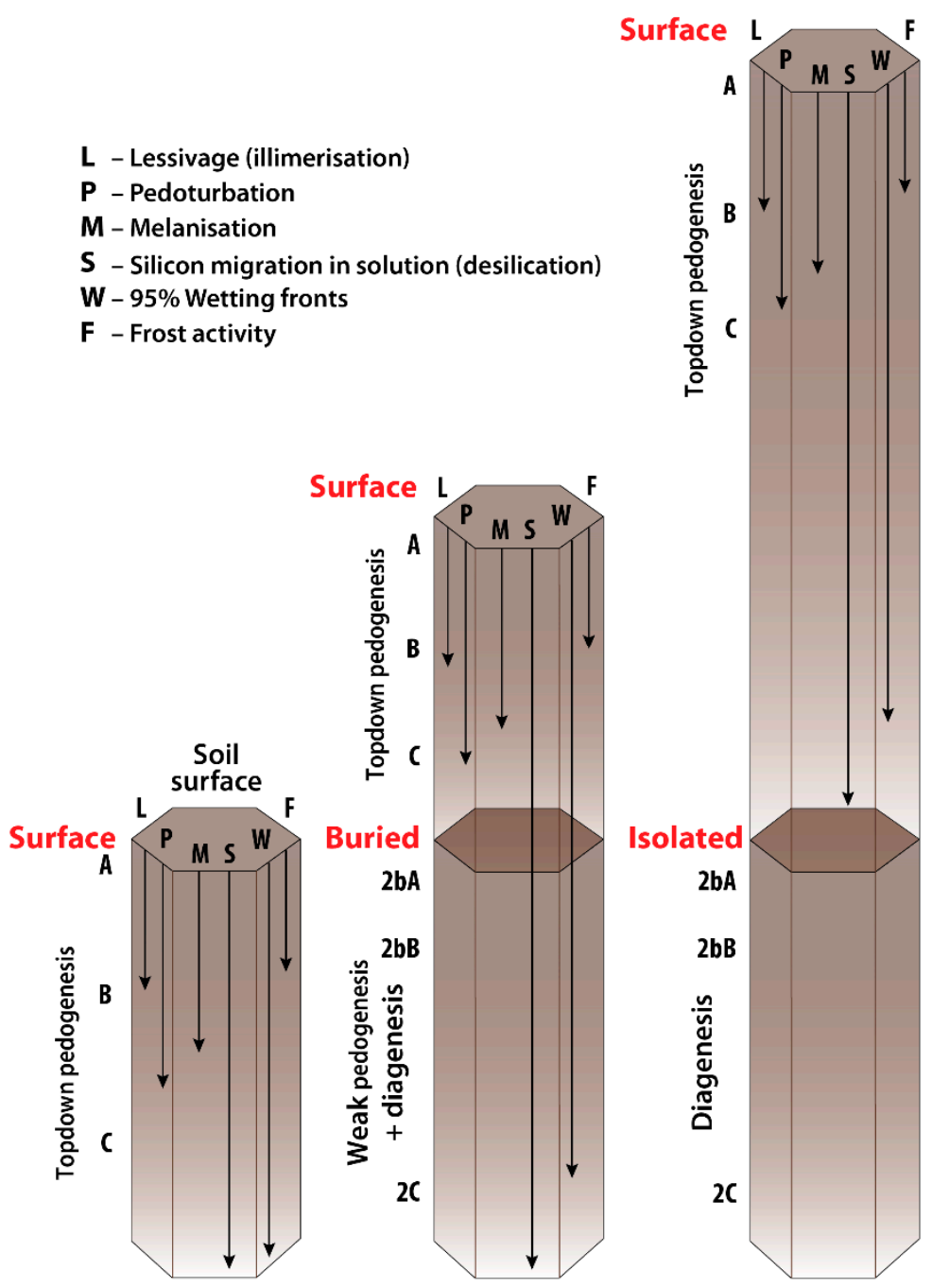

Figure 7. Idealized model of the relative depth of burial of paleosols and their alteration by pedogenic processes acting largely from the surface downwards (arrows). Once a paleosol is isolated any changes may be regarded as largely diagenetic, not pedogenic, especially when cut-off completely from surface processes [44]. Diagenesis is the post-depositional, low-temperature alteration of geological deposits or (buried) soils [131], which contrasts with alteration via pedogenesis in modern (surface) soils. Diagenesis may overlap with soil welding, which has occurred in the older Hamilton and Kauroa Ash beds as described in the text. Modified after [24] (p. 608), following [132], with permission of the publisher.

A corollary associated with developmental upbuilding is that each part of the profile/pedon has, at one time, been an ' $\mathrm{A}$ ' horizon [111,124], which helps to explain the pedogenic fabric evident in the horizons making up the upper 'storey' of the Kainui soil [55,109]. A second corollary is that the soil is polygenetic, the upper c. $0.6 \mathrm{~m}$ having developed during MOIS 3 to 1, even though it is a 'modern' soil at the land surface today. This conclusion is entirely consistent with, and indeed supports, the dynamic-rate model of soil evolution $[127,133]$ as well as complementing studies on loess-paleosol sequences in China and elsewhere [27,116-118]. 

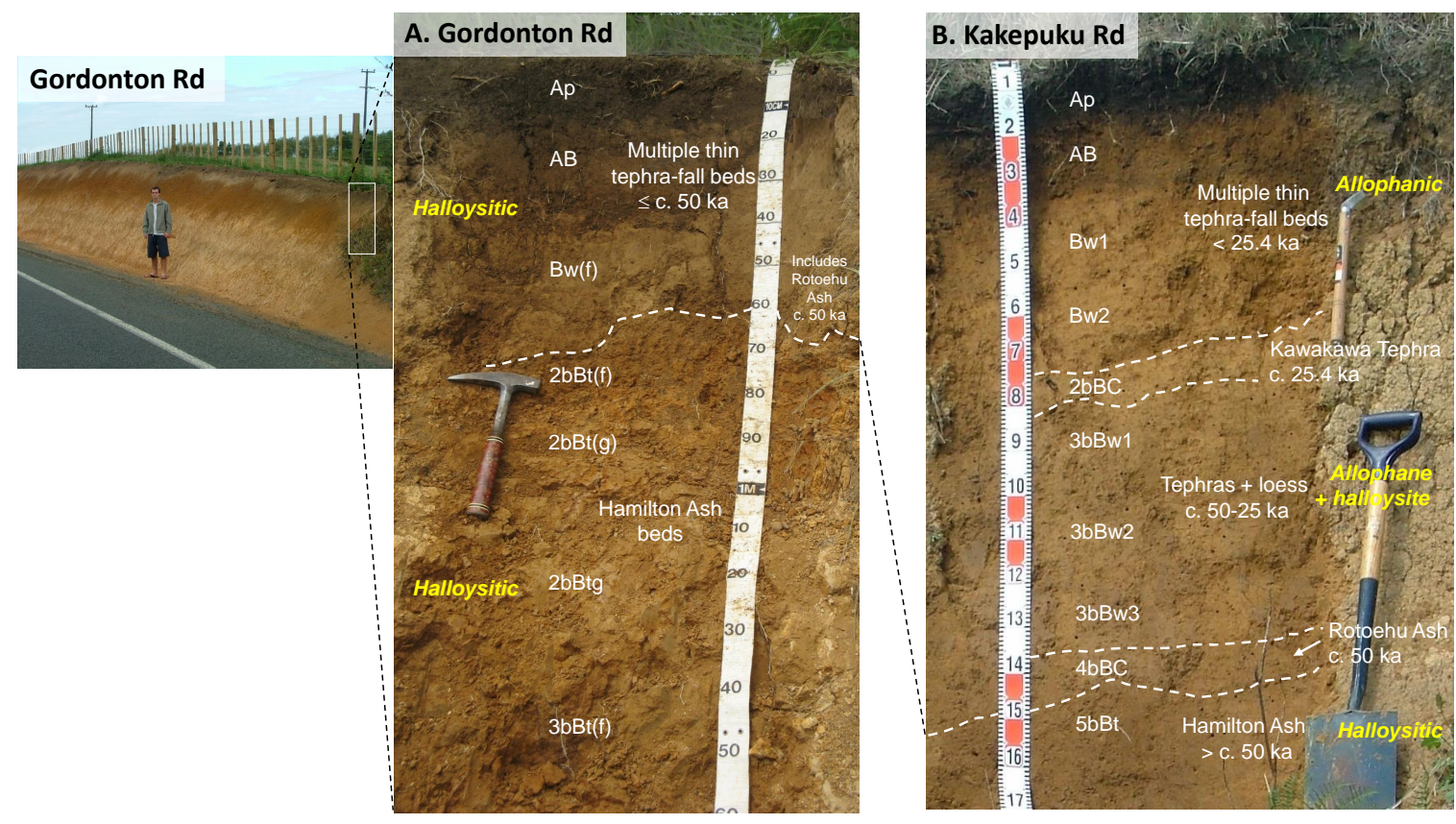

Figure 8. (A) Profile of the Kainui silt loam at Gordonton Road ( $37^{\circ} 42^{\prime} 23^{\prime \prime}$ S, $175^{\circ} 18^{\prime} 18^{\prime \prime}$ E), elevation c. $30 \mathrm{~m}$ asl, comprising two distinctive parts separated by a lithological discontinuity (dashed line). The soil has a thermic soil temperature regime but only just, being very close to mesic [34]. Formed by developmental upbuilding pedogenesis, each component of the upper profile has previously been an 'A' horizon whilst the land surface has risen slowly since c. $50 \mathrm{ka}$ as thin tephras were accreted at the site at a mean rate of c. $1.2 \mathrm{~mm} /$ century. Redoximorphic features in the moderately well drained $\mathrm{Bw}(\mathrm{f})$ horizon ( $>2 \% \mathrm{Mn}-\mathrm{Fe}$ concretions with some $\mathrm{MnO}_{2}$ coatings or mangans) indicate prolonged periods near to saturation because of perching on the buried paleosol marked by the $2 \mathrm{bBt}(\mathrm{f})$ horizon. Consequently, the entire soil is dominated entirely by the 1: 1 kaolin-subgroup clay mineral, halloysite, not allophane (an aluminosilicate nanomineral), because of limited desilication (see text). Annual rainfall at this site is c. $1200 \mathrm{~mm} / \mathrm{yr}$. The soil horizonation nomenclature used here and in other figures is based on [46]. The prefix ' $b$ ' is used to denote an identifiable soil horizon with pedogenic features developed before its burial. (In NZSC, ' $b$ ' is a prefix; in ST, it is a suffix.) The soil is a Buried-granular Yellow Ultic Soil in NZSC [11] and a Typic Kandiudult in ST [34]. A commercial tea plantation nearby is located in part on soils essentially identical to this one (Figure 4). Photo: R. McEwan. (B) Profile of the Otorohanga silt loam (of the Otorohanga series, referred to as 'Otorohanga soil' elsewhere in text) exposed on the low-angle shoulder of near-level summit in rolling hills at a site on Kakepuku Road ( $38^{\circ} 03^{\prime} 58^{\prime \prime}$ S, $175^{\circ} 16^{\prime} 43^{\prime \prime}$ E), c. $25 \mathrm{~km}$ south of the Gordonton Road site (Figure 1). The soil is at an elevation of c. $57 \mathrm{~m}$ asl and has a mesic soil temperature regime [34]. The upper $1.5 \mathrm{~m}$ comprises essentially the same late Quaternary tephras (dating back to c. $50 \mathrm{ka}$ ) that occur at Gordonton Road (Figure 8A) but their moderately greater thicknesses and hence greater depth to the buried clayey and less-permeable soil horizon (5bBt) on Hamilton Ash, together with a slightly higher annual rainfall (c. $1400 \mathrm{~mm} / \mathrm{yr}$ ) and somewhat greater (but still subordinate) andesitic tephra component [18,36], ensure that the upper soil has remained well drained with strong desilication and high $\mathrm{Al}$, thereby favouring the formation of allophane $[18,59,110,134]$ (see also text). The mean rate of accumulation of post-Rotoehu-Ash tephras (plus minor tephric loess) at this site is only c. $2.8 \mathrm{~mm} /$ century but it is more than twice the rate at Gordonton Road and a markedly different soil has ensued. The formation of allophane and the clustering of its constituent tiny spherules into micro- and nanoaggregates [135], generating high porosity and low bulk density [110], is self-reinforcing by enhancing matrix-flow drainage and promoting further desilication. The soil reflects developmental upbuilding pedogenesis, most parts of the profile being an 'A' horizon at some point. It is a Typic Orthic Allophanic Soil in NZSC and Typic Hapludand in ST [11,34]. Photo: D.J. Lowe. 


\subsection{Importance of Lithologic Discontinuity}

That the boundary between the upper and lower storeys is a lithologic discontinuity, denoted by the prefix ' 2 ' in the horizon notation (Figure $8 \mathrm{~A}$ ), and an unconformity (a paraconformity), is an important denouement because it counteracts and negates several other ideas of soil genesis that had been invoked previously. A lithologic discontinuity is a contact between two genetically unlike deposits or other geological materials, characterized (for example) by a change in grain-size or primary composition (mineralogy) caused by a geological event or processes rather than pedogenic processes $[24,46]$. Regarding the Kainui soil, one foregoing hypothesis was that the buried soil horizon (2bBtg) on the upper Hamilton Ash (Figure 8A) was an argillic horizon (it is, but as a relict feature in a buried paleosol); another was that it was a podzolic-B (spodic) horizon. Both hypotheses assumed the $2 \mathrm{bBtg}$ horizon to be genetically connected by the eluviation of clays, or by the eluviation of $\mathrm{Fe}, \mathrm{Al}$ and $\mathrm{Si}$, from the upper to lower parts of the soil, forming a sequum, as contended by McLeod [51]. A sequum comprises a pair (couplet) of soil horizons, one characterised by eluviation (loss of material), often forming an $\mathrm{E}$ and an associated underlying horizon characterised by complementary illuviation (gain of material), usually a Bt or Bs or Bh (e.g., Reference [24]). A multisequal soil has more than one sequum in its profile. But the upper and lower profiles of the Kainui soil are probably not directly connected genetically (or they have been connected for only a limited period): the buried soil has properties (including, as mentioned already, features that qualify it as kandic and argillic horizons in ST) that relate to its formation at an earlier time, probably during the Last Interglacial (Figure 3) [17]. The kandic and argillic horizons are therefore best envisaged as paleo-argillic and paleo-kandic horizons (see Section 4 on classification below). New Zealand Soil Bureau [136] (pp. 90-91) had provisionally recognised this lithological discontinuity, the lower horizons of the Kainui-equivalent soil on Church Road (the 1968 reference site for the so-called 'Hamilton clay loam') being classed as (II) $B_{21}$ and (II)B $B_{22}$ horizons, with the text describing the parent material including this sentence: "The ash in the upper 16 in. [inches] [c. $40 \mathrm{~cm}$ ] was probably deposited after a considerable interval of soil formation on the older ash deposits' (p. 90). The Roman-numeral prefix 'II' (today the Arabic prefix ' 2 ' is used both in NZSC and ST) also indicated a lithological discontinuity [137] but the parentheses showed some uncertainty at that time.

\subsection{Clay Mineralogy}

The partially weathered coverbed of late Quaternary tephras is dominated by halloysite, not allophane, in the clay fraction. Halloysite is a 1:1 kaolin-subgroup aluminosilicate clay mineral; allophane is a nanocrystalline aluminosilicate clay comprising tiny spherules c. 3.5 to $5.0 \mathrm{~nm}$ in diameter with a chemical composition in the range (1-2) $\mathrm{SiO}_{2} \cdot \mathrm{Al}_{2} \mathrm{O}_{3} \cdot(2-3) \mathrm{H}_{2} \mathrm{O}$ [44]. Nanocrystalline clays have structure in the nanoscale range, that is, $1-100 \mathrm{~nm}[44,138,139]$. Earlier, this halloysitic dominance had been a major puzzle because the formation of halloysite was erroneously thought to follow, by some c. 10,000 to c. 15,000 years, the formation of allophane [18,44]. However, the development of the Si-leaching model explained that the formation of allophane or halloysite depended in part on the amount of silicon in soil solution (and availability of aluminium), which in turn was controlled by rainfall, drainage, depth to slowly permeable layer and other factors [54,140-142], age being indirect and subordinate $[18,130]$. This is another key finding. That 'young' tephras could weather directly to halloysite, exemplified in the Kainui soil, was therefore described as 'the leopard that changed its spots' $[109,130]$. A silica-rich environment favours the formation of halloysite instead of allophane, as expressed by the Si-leaching model (summarized by $[44,143,144]$.

Under this model, both allophane and halloysite can form directly from the synthesis of the products of dissolution of volcanic glass and primary minerals along different pathways according to local environmental conditions, subject to kinetic and thermodynamic constraints $[18,54,140,145,146]$. Halloysite formation is favoured by a Si-rich environment ( $\mathrm{Si}$ concentrations in soil solution are $>\mathrm{c}$. 10-15 ppm) or a wet, even 'stagnant,' soil moisture regime, whereas allophane, on the other hand, 
forms preferentially in free-draining situations where Si concentrations in soil solution are low (<c. 10 ppm), allowing Al-rich allophane to develop [44,141,147-149].

The Kainui and Otorohanga soils, despite occurring in identical geomorphic positions (mainly on rolling hills), thus have markedly different clay mineralogies in their upper soil horizons. The explanation relates to multiple factors [14,18] but four key aspects are summarised as follows.

(i) The depth to the slowly-permeable (buried) paleosol in the Kainui soil is less than a critical threshold of c. $0.8 \mathrm{~m}$ below the land surface (see the approximate boundary line marked in Figure 1): soils with a late Quaternary tephra mantle >c. $0.8 \mathrm{~m}$ in thickness are almost invariably allophanic in upper profiles, usually forming Andisols (provided thickness criteria are met), whereas soils with a thinner coverbed $\leq$ c. $0.8 \mathrm{~m}$ are usually halloysitic, forming Ultisols.

(ii) Rainfall generally decreases somewhat from south to north across the Hamilton lowlands (c. $1400 \mathrm{~mm}$ per year at Kakepuku Road to c. $1200 \mathrm{~mm}$ per year at Gordonton Road, dropping to c. $1100 \mathrm{~mm}$ or less farther to the north and east) $[18,73,150]$, reducing the potential throughflow of silicon in soil solution through the soil [54]. Winter through-drainage in the Otorohanga soil is likely to be >c. $550 \mathrm{~mm}$; that in the Kainui soil is c. $400 \mathrm{~mm}$, probably considerably less in some years (after [143]). A frequently occurring (c. 70\% of years) late summer or early autumn soil moisture deficit, usually lasting several months (typically from c. 30 to 50 median annual days), is generally most pronounced north and northeast of Hamilton [73,150]: the potential summer soil moisture deficit for the Kainui soil is likely to be c. $170 \mathrm{~mm}$; that for the Otorohanga soil is probably <c. $140 \mathrm{~mm}$ (after [54,73,151,152]). Generally, rainfall during glacial periods is reduced by up to c. $25 \%$ of that of the present, e.g., $[153,154]$, and therefore halloysite formation rather than allophane is promoted in such times because of limited desilication, as evident in the middle to lower profile (below c. $0.9 \mathrm{~m}$ depth) of the Otorohanga soil (Figure 8B). From c. 0.9 to $1.5 \mathrm{~m}$ depth, both allophane and halloysite have been formed in the Otorohanga soil, very likely during MOIS 3 and 2 when the parent tephras and tephric loess were being deposited and simultaneously weathered and altered by pedogenesis during a mainly (but not wholly) drier and cooler climate [54,102,155-157]. That allophane or halloysite, or both, were able to form depends on whether Si concentrations in soil solution were above or below, or, at times, fluctuating around the c. 10-15 ppm threshold of Singleton et al. [141], and if kinetic and thermodynamic conditions were appropriate [44].

(iii) The primary composition of the composite tephras of the upper coverbed comprises a mix of rhyolitic and andesitic tephras [18,36,37]. Although the amounts of rhyolitic glass (with high silica, c. $78 \mathrm{wt} \%$, and moderate alumina, c. $12 \mathrm{wt} \%$ ) always exceed those of andesitic glass (with moderately high silica, c. $62 \mathrm{wt} \%$, and high alumina, c. $17 \mathrm{wt} \%$ ) $[18,110]$, the tephras in the southwest parts of the Hamilton lowlands, such as at Kakepuku Road in Waipa District (Figure 1A), have a proportionally higher andesitic component (up to c. 30-35\%) than in the northern and north-eastern parts (up to c. 10-15\%) as demonstrated by analyses of the lacustrine tephras across the Hamilton lowlands (Figure 1A) [18,36,37] because the southern locations are a bit closer to the main source volcanoes of andesitic tephras, Tongariro and Egmont (Taranaki) (Figure 1B). This general 'compositional gradient' thus enhances the formation of Al-rich allophane in southern/southwestern areas and halloysite in northern/north-eastern areas [59].

(iv) As the tephras accumulate on stable sites, they, being mainly siliceous to very siliceous, provide an ever-thickening 'overburden' (thickening coverbed and concomitantly rising land surface) and hence effectively contribute a more-or-less persistent supply of silica and alumina, e.g., $[18,158]$. This situation may be compared with the dissolution kinetic-fluid flow coupling model developed by Shikazono et al. [159] to explain the ongoing generation and downward migration of monosilicic acid from the weathering of multiple middle- to late-Holocene basaltic tephra layers that had accumulated layer by layer in central Japan. The coupling model was also invoked to help explain abundant halloysite formation at depth in thick accumulating Quaternary-aged siliceous tephras and derivatives in eastern North Island [131]. In the coupling model, rainwater 
migrates downwards through a glass-dominated tephra layer (in effect a 'silica reservoir') and reacts with the volcanic glass, which dissolves through hydrolysis, the dissolution products [Si] and [Al] then crystallizing together as halloysite. A new layer/reservoir of freshly-deposited glass (along with felsic and mafic minerals) at the land surface provides a new source of silica (and alumina, to a lesser degree) as the soil water moves down through it [159].

The different weathering pathway-forming halloysite rather than allophane in the upper soil horizons-is shown by the contrast between the Kainui soil (Figure 8A) and the Otorohanga soil (Figure 8B), both derived from late Quaternary tephras. In fact, the inverse atomic structures of allophane versus halloysite preclude the possibility of allophane transforming to halloysite other than by completely dissolving and reforming [110,134,160-162]. The presence of redox segregations, especially $\mathrm{MnO}_{2}$-concretions towards the base of the late Quaternary tephra coverbed, supports the Si-leaching model because these wet-dry features show that desilication has been limited to some considerable degree by impeded drainage, the soil's upper horizons being moderately well drained [163]. The text in Section 5 below, 'Caught in the act,' highlights the importance of moderate gleyisation in the upper Kainui soil through perching.

\section{Classification}

The classification (taxonomy) of the Kainui soil has been troublesome in that the soil, despite its relatively 'young' (late Quaternary) tephra-derived origins, did not fit into the Yellow-brown loams (allophanic by definition) of the earlier New Zealand Genetic Soil Classification [164] because it was clearly non-allophanic $[35,165]$. Nor did it sit well in the Brown-granular loams (typically formed on weathered Hamilton Ash beds) because the 'granular' character (distinctive, well-expressed polyhedral pedality or soil fabric) [11] associated with this group was at a depth typically half-a-metre or more below the land surface. Instead, the two-storeyed nature of the Kainui soil was suitably reflected by its classification in some publications as a composite Yellow-brown earth on (pre-weathered) Brown-granular loam $[35,42,48,49,51]$. In NZSC, the Kainui soil was initially placed in the order of Granular Soils (first and second editions) but I thought the earlier composite classification was better because it was tailor-made for the whole ( $\geq 1-\mathrm{m}$ deep) profile morphology. Hence in the third edition of NZSC, a special class in the Ultic Soils was developed for the Kainui soil, which, uniquely, is now a Buried-granular Yellow Ultic Soil; tephric; not applicable (mixed rhyolitic >> andesitic fines); silty/clayey; moderate/slow [11,52].

In contrast, the online S-map soil reports ('fact-sheets') for the Kainui family record that siblings fall in the Podzolic Yellow Ultic Soils. This designation matches that for an unpublished soil profile description associated with the Hauraki survey (reported in Reference [55], pp. 66-67) in which dark brown (7.5YR 4/2) "organic matter down cracks" was described in the lower subsoil. Such an occurrence helped allow the soil to be placed in the Podzolic subgroup of the Yellow Ultic Soils [53], a second criterion being the requirement that the $\mathrm{E}$ horizon had a $\mathrm{pH} \leq 4.8$ together with the need for $10 \%$ humus coatings or coatings of colour value 4 [11]. The colour value of 4 alone would be enough-even if the 'organic matter' were actually dark-coloured redox-derived $\mathrm{MnO}_{2}$-coatings (mangans) of pyrolusite rather than illuviated humus, as suggested by Lowe [55]—along with the strong acidity. My preferred classification is the 'Buried-granular' rather than the 'Podzolic' subgroup because, as discussed below, the upper and lower storeys of the profile do not form a sequum - that is, strictly, they are not genetically connected-and so a podzolic origin would seem less appropriate (and would be incorrect anyway if illuviated humus were absent and the low $\mathrm{pH}(\leq 4.8)$ threshold were not met [55]).

The 'ultic' character is well expressed in ST [1]. The soil depicted in Figure 8A is a Typic Kandiudult; fine-silty over clayey, halloysitic, thermic [34]. Although the profile contains a buried soil, the coverbed is not "new material" as defined in Soil Taxonomy because such material is described as "largely unaltered" [1] (p. 10) and hence the special rules for classifying buried soils are not triggered $[1,166]$. That the paleo-argillic and paleo-kandic horizons are largely relict is not taken into 
account but nor should they be, given that ST is to a large degree (but not entirely) morphological in focus. In other words, understanding the way the soil behaves in its management is paramount given the main purpose of ST as a "basic system of soil classification for making and interpreting soil surveys" [1,6]. An intriguing final thought is that the Kainui soil, although in toto an Ultisol, which implies 'old', is nevertheless continuing to receive contemporary (modern) ash-fallout on its surface from time to time.

\section{Caught in the Act: Seasonal Perched Gleying (Reduction) in the Kainui Soil}

Each year I take undergraduate students to see and describe a range of soils on the classic soil-landscape sequences of the Hamilton lowlands $[42,60,167]$. Normally run in March or early April (i.e., late in the austral summer), the field trip in 2018 was in late September (i.e., in the austral spring). In addition, a large class size meant I opened up two soil pits rather than the usual one to represent the Kainui soil to cope with the greater numbers. The two pits were on middle-backslope positions on a low hill just off Swallow Lane near Hamilton (Figure 1), one pit being slightly higher than the other on the slope (Figure 10).

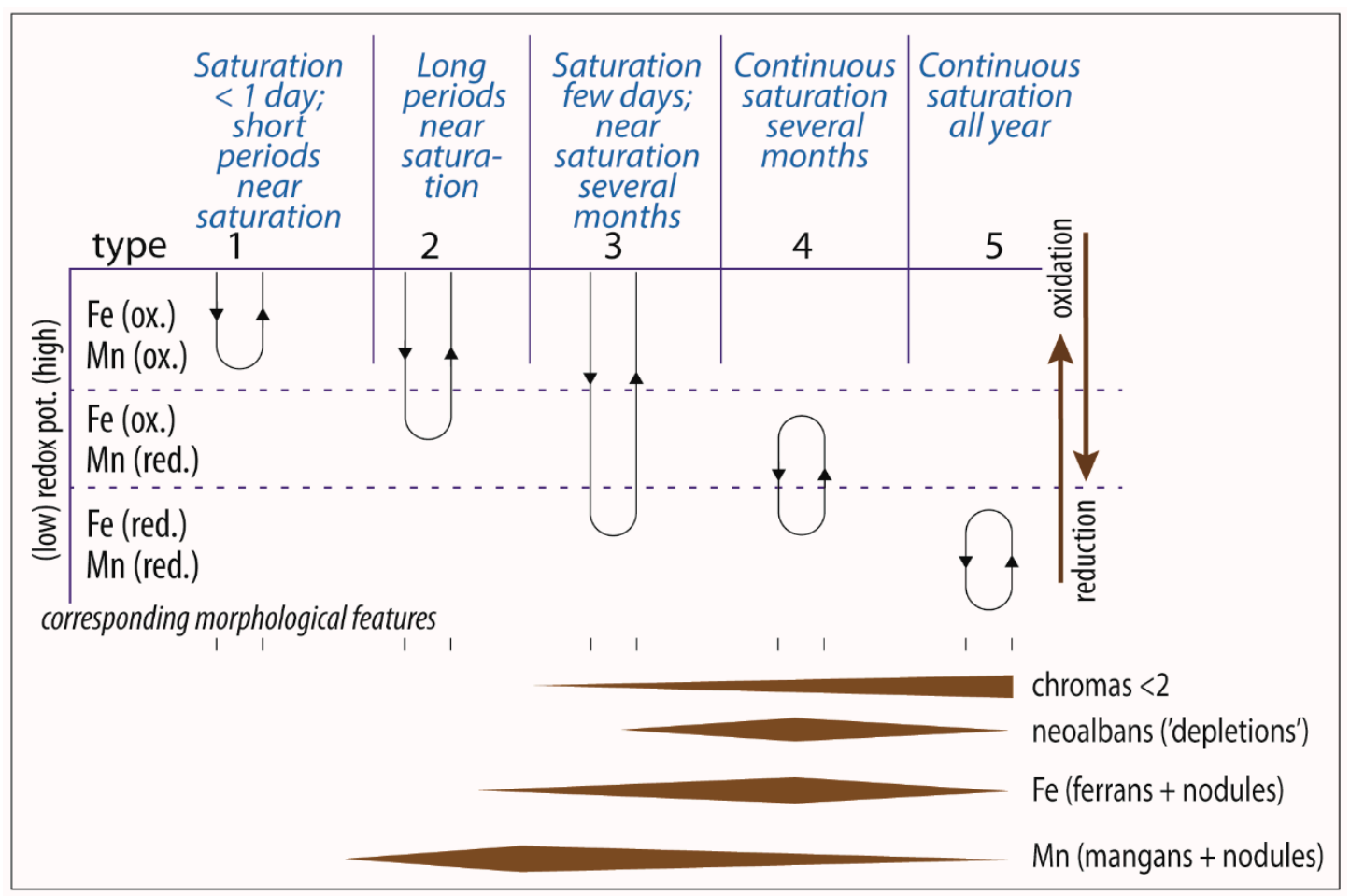

Figure 9. Schematic diagram of approximate soil-moisture redox conditions (potential) and resulting redox (or redoximorphic) features and different associated soil types designated 1-5. The Kainui soil's redox features, such as at Swallow Lane and Gordonton Road, would place it normally between types 2 and 3. Pot., potential; ox., oxidized; red., reduced. Redrawn after [168] (p. 135), following [169] (p. 273), with permission of the publisher. Note that slightly different terms are used regarding soil redox features in New Zealand (NZ) [11,46,163] and the United States (USA) [47], with some approximately equivalent terms as follows: redox segregations (NZ) = redox concentrations (USA); low chroma colours (in matrix or on ped faces) (NZ) = redox depletions (USA); low chroma matrix or reductimorphic horizon $(\mathrm{NZ})$ = reduced matrix (USA); redox-mottled horizon $(\mathrm{NZ})=$ redoximorphic features (USA). 

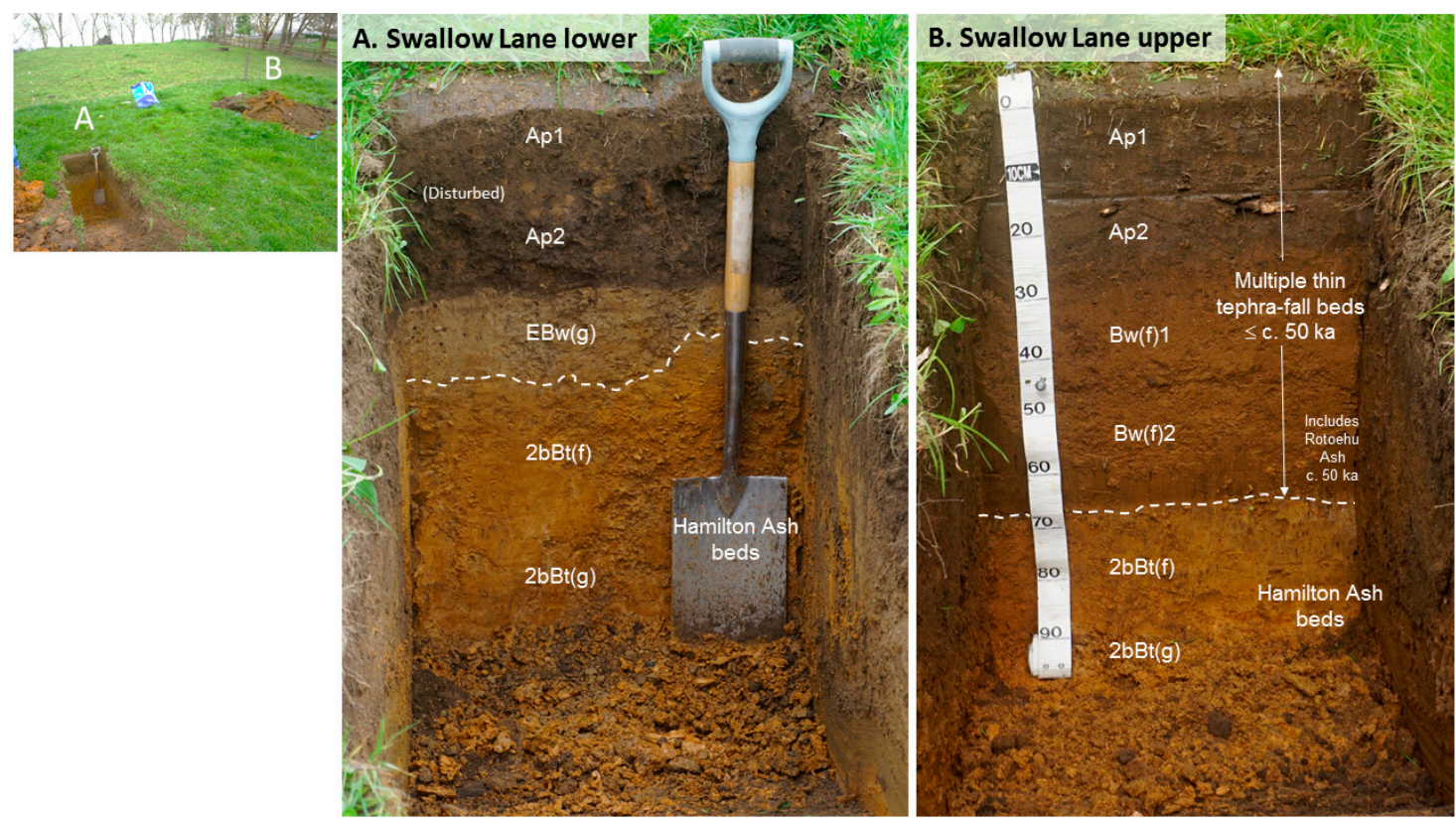

Figure 10. Two pits exposing the Kainui silt loam on a backslope position, elevations c. 54 and $55 \mathrm{~m}$ asl, on a low hill at Swallow Lane $\left(37^{\circ} 49^{\prime} 23^{\prime \prime}\right.$ S, $175^{\circ} 22^{\prime} 49^{\prime \prime}$ E) near Hamilton (Figure 1) in September, 2018. Mean annual rainfall here is c. $1200 \mathrm{~mm} / \mathrm{yr}$. In both pits the ' $\mathrm{A}$ ' horizons have been overthickened. (A) Kainui soil with the lower part of the upper profile, the EBw(g) horizon, 'caught in the act' of having contemporary reducing conditions (gleying), the water perching above the clay-rich, relatively impermeable buried soil horizons on Hamilton Ash. The spade is c. $1 \mathrm{~m}$ high. (B) Kainui soil with a 'normal' oxidised profile, although the redox segregations in both Bw(f) horizons provide definitive evidence of periodic gleying taking place as can be seen in profile A. Redox segregations are formed as a result of the reduction and solubilisation of manganese or iron or both, their translocation and concentration and their re-oxidation and precipitation in the form of oxides [44,46] (Figure 9). Photos: D.J. Lowe.

A dramatic feature of the lower-placed profile was the decidedly pale colour of the EBw $(\mathrm{g})$ horizon immediately above the slowly-permeable, clayey buried soil horizon, $2 \mathrm{bBt}(\mathrm{f})$, on Hamilton Ash (Figure 10A). (I will explain the suggested transitional nature of this horizon shortly.) Clearly wet with contemporary reducing conditions and although obviously pale in the fresh pit face, the EBw $(\mathrm{g})$ horizon in pit A only marginally qualifies as such in that low chroma colours, as specified for a Bg horizon (which needs a moist chroma $\leq 2$ or a moist chroma of 3 and a value $\geq 6$; [46]), were barely met: the horizon mainly had Munsell colours (moist) of 10YR 5/3-5/4 (brown-yellowish brown) but close inspection revealed in some parts $(<50 \%)$ matrix colours (moist) of 10YR 6/3-6/4 (pale brown-light yellowish brown) and even 10YR 7/1-7/2 (light grey). Given the obvious contrast with the darker colours of the adjacent soil in pit B and the importance with respect to genesis, I consider the bracketed $(\mathrm{g})$ designation to be appropriate. (To qualify as a Bg-no parentheses around the ' $\mathrm{g}$ '-would require colours (moist) of 10YR 6/3 or paler to occupy 50-85\% of the matrix [46], which is not quite the case here.) The morphology and geomorphic position point unequivocally to gleyisation through perching on the $2 \mathrm{bBt}(\mathrm{f})$ soil horizon on Hamilton Ash and contrast with the darker colours and oxidising conditions evident in the soil in the higher-placed pit B (Figure 10B). Normally, this gleyisation is hidden, only being inferred from the redoximorphic features (redox segregations) that characterize the lower part of the late Quaternary tephra coverbed. However, because we had dug the pits in spring after a lot of rain, the soil in Figure 10A had effectively been 'caught in the act' of short-term seasonal gleying.

In some locations, the lower subsoil horizon of the Kainui soil (in the coverbed deposits) has, as noted above, previously been designated also as an E horizon [50,51,55], with Ew(g) being an 
alternative to $\mathrm{Bw}(\mathrm{g})$ on the basis of colour and $>2 \% \mathrm{MnO}_{2}$ concretions [46]. However, although qualifying morphologically, the definition of an E horizon includes the imperative concept that the horizon has lost material "as a result of downward or lateral movement" [46] (p. 9). The same imperative is stated in ST [34] (p. 335). Has there been such movement and loss? It cannot be definitively ruled out. However, as discussed above, the lithological discontinuity beneath a notional E horizon means that it and the $2 \mathrm{bBt}(\mathrm{f})$ horizons do not form a true sequum and therefore only limited time has been available for any eluviation and illuviation to have taken place, with most or all of the clay in the $2 \mathrm{bBt}(\mathrm{f})$ being relict (discussed further below). In the case of the soil in pit A at Swallow Lane (Figure 10A), seasonal reduction, not eluviation, is responsible for the low chromas. A neat solution to the dilemma regarding $\mathrm{E}$ versus $\mathrm{B}$ horizonation for the lower subsoil of the coverbed is provided by Clayden and Hewitt [46]. They state that "Where the lower boundary is a lithological discontinuity and there is no clear evidence of an illuvial relationship with the underlying $2 \mathrm{~B}[\mathrm{t}]$ horizon, the notation EBw is used" (p. 11). Hence I have designated the pale horizon in pit A (Figure 10A) as an EBw(g). In addition, both this horizon and the Bw(f) horizon in pit B (Figure 10B) could be qualified further by the additional suffix ' $\mathrm{p}$ ' for perched [46], giving (if we wanted to go the whole hog) an EBw(gp) in pit $A$ and $B w(f p) 1$ and $B w(f p) 2$ in pit $B$.

The $\mathrm{MnO}_{2}$-dominated redox segregations indicate that the soil spends long periods (several months) near saturation or is saturated for several days each year (Figure 9). These conditions, nevertheless, are not quite sufficient to push the soil into the 'aquic' regime of ST (cf. classification in Reference [51] p. 24).

\section{The Buried Soil on the Upper Hamilton Ash Beds}

Although we now understand the origins and character of the upper storey to a much better extent than before, the buried paleosol on the upper Hamilton Ash beds (the lower storey) remains enigmatic, mainly because it is so weathered and altered and hence has few remaining primary minerals. Of the entire Hamilton Ash sequence, originally defined by Ward [61] (see also [64]), only the basal unit, H1, which is known as Rangitawa Tephra, has been dated directly (Figure 3). The white, c. 0.5-m-thick Rangitawa Tephra is c. $340 \mathrm{ka}$ in age. Erupted from Whakamaru Volcanic Centre (Figure 1B) as the product of a super-eruption [170], it fell late in MOI Stage 10, thereby providing a key paleoclimatic marker throughout New Zealand and beyond for this period [65,171-175]. Rangitawa Tephra is overlain in turn by a c. 3-m thick sequence of weathered, yellowish brown to brown to reddish brown weathered, clayey tephra beds and buried soils—-the Hamilton Ash beds-that must represent MOIS 9 to 5 (Figure 3) [55]. Partly on the basis of the distinctive colour differences and other physical properties of the beds in the sequence, their clay mineral assemblages [14], and climatostratigraphic associations $[20,176,177]$ established in King Country, Taranaki, and Whanganui regions (Figure 1B) for deposits and paleosols of similar age, the uppermost distinctive, dark reddish-brown buried soil (known also as the Tikotiko Ash or bed H6/7) [61,65], probably represents the Last Interglacial (MOIS 5e) with an age of c. $125 \mathrm{ka}[178,179]$. Following Stage $5 \mathrm{e}$ and subsequent interstadials $(5 \mathrm{c}$, $5 a)$ and stadials $(5 d, 5 b)$, marked cooling into the Last Glaciation began at c. 74 ka. Therefore, the pit-mound windthrow features (Figures 2 and 3) on the paleo-surface on the upper Hamilton Ash allow an approximate minimum age of c. $74 \mathrm{ka}$ to be inferred for this (paleo)surface because forest cover, almost certainly very extensive during MOIS $5 \mathrm{e}$ and prevalent during MOIS $5 \mathrm{~d}-5 \mathrm{a}$ based on data in References [22,85,179-181], was likely reduced to remnant or refugia status in the Hamilton lowlands (central Waikato region) after c. $74 \mathrm{ka}$, with shrubland-grassland being predominant during the ensuing 'extended' Last Glacial Maximum in New Zealand from c. 30 to 18 ka [157,178,182,183].

Such an age for the paleo-surface could be tested in various ways: (i) using radiometric dating methods on the upper Hamilton Ash beds provided appropriate zircons could be extracted e.g., [184]; (ii) by making paleomagnetic measurements to try to identify the Pringle Falls Excursion at c. $220 \mathrm{ka}$ and the Blake Excursion at c. 120 ka [185-189]; or (iii) by extracting quartz grains containing melt 
inclusions (i.e., glass) for analysis by electron microprobe as a tephrochronological compositional or 'fingerprinting' tool e.g., [26,69,190].

Another interesting feature of the weathered Hamilton Ash beds wherever they occur is that nowhere are any primary tephra layers (with abundant unweathered glass shards and felsic and mafic mineral grains) evident except for the basal Rangitawa Tephra (H1) —all beds are invariably clay-rich and altered [61,64,65]. Bakker et al. [17] indicated that the Naike clay ('Naike soil' hereafter), which is an equivalent (paleo)soil formed on Hamilton Ash that has been exhumed and which frequently occurs spatially alongside the Kainui soil [55], becomes more weathered with depth. This relationship suggests that developmental upbuilding pedogenesis has predominated in its formation (the deposition of the relatively thick Rangitawa Tephra, however, representing a retardant upbuilding event). In turn, such an origin implies that very large numbers of (thin) tephra-fall deposits make up each of the now-undifferentiated, clayey beds of the Hamilton Ash sequence (which may also contain intercalated loessic deposits at some sites: [191]). The entire sequence of Hamilton Ash beds (Figure 3) may best be envisaged therefore as a (giant) composite, welded paleosol, effectively the end stage of developmental upbuilding pedogenesis over a long period whereby the solum of each surface soil (each eventually becoming a buried paleosol) has merged with, or been superimposed on, the one beneath via soil welding $[117,132,192]$ as the land surface has slowly risen over a period of c. 200,000 years (i.e., from c. 340 to $125 \mathrm{ka}$ ). The sequence represents an extreme case of polygenesis (or 'polycyclicity' of Reference [117]).

Another sequence, namely the Kauroa Ash beds (which are up to c. $12 \mathrm{~m}$ thick in western Waikato), dating from >c. $0.78 \mathrm{Ma}$ to c. $2.3 \mathrm{Ma}$, continues well below the Hamilton Ash beds and basal Rangitawa Tephra $[65,66,68,71]$. The paleosols making up the Kauroa Ash sequence thus form an even older, extended composite or accretionary, welded paleosol that represents up to c. 1,520,000 years of developmental upbuilding pedogenesis [130] during almost the entire Early Quaternary-that is, from c. $2.3 \mathrm{Ma}$ to c. $0.78 \mathrm{Ma}$.

Therefore, are 1-m-deep soils, such as the Otorohanga soil (Figure 8B), formed by developmental upbuilding, destined to end up (in, say, another c. 50,000 years) as a rather homogenous-looking, welded, halloysite-rich clayey unit as seen throughout the Hamilton Ash (and Kauroa Ash) sequences? Churchman and Lowe [44] and Moon et al. [149] (indirectly) addressed this question with respect to the likely clay mineral composition by considering longer timescales of glacial and interglacial cycles in temperate volcanic landscapes not directly glacierized, as was the case for most of North Island, e.g., $[154,183]$. They pointed out that the marine oxygen isotope records show that cooler and drier conditions associated with glaciations persisted c. $80-90 \%$ of the time whereas warmer and wetter conditions associated with interglaciations occurred only c. $10-20 \%$ of the time. In northern New Zealand landscapes, where long sequences of tephras and associated deposits and palesosols are generally well preserved, therefore, it might be expected that soils developed from such accumulations dating back several hundreds of thousands of years to one or two millions of years, as evident in the Kauroa and Hamilton ash sequences, should be dominated by halloysite rather than allophane because a drier climate during cool or cold glacial periods favours halloysite formation [20,44], as discussed above.

\section{Micromorphology}

Clay coatings and other micromorphological features in the (now buried) paleo-argillic and paleo-kandic horizons in the weathered upper Hamilton Ash beds match those identified in the Naike soil [17]. Bakker et al. [17] wrote that the laminated character of the clay coatings in the Bt horizons of the Naike soil indicates that clay illuviation has taken place and that the fine-clay/total-clay ratios for the Naike soil are consistent with this interpretation. The clay skins, infilling pores, then led to the formation of iron (hypo) coatings [17], all of which takes time. The question then arises as to the source of the translocated clays in the $2 \mathrm{bBt}$ horizons in the Kainui soils because, as has been discussed, the upper late Quaternary tephra coverbed accumulated only during the past c. 50,000 years, meaning that 
overlying tephra/soil materials to potentially provide an eluvial source of fine clays were absent or relatively thin for much of the time, because the tephras accumulated incrementally only after c. $50 \mathrm{ka}$. Also, the upper coverbed can comprise $\mathrm{Bw}(\mathrm{f})$ and $\mathrm{Bw}(\mathrm{g})$ horizons that are pale because of seasonal gleyisation rather than because of eluviation. Could additional tephras covering the $2 \mathrm{bBt}$ horizons at the time of the Last Interglacial have been eroded in MOIS 4, with cooling c. 67-62 ka now known to be sufficiently severe to warrant this stadial being described by some as 'a full glacial' [157,178,193], and then effectively replaced during and after MOIS Stage 3 by the Rotoehu Ash and ensuing younger coverbed tephras we see today (Figure 3)?

\section{Summary and Conclusions}

(1) Ultisols comprise a group of important soils with illuvial clay-enriched and moderately to strongly acid subsoils and generally low fertility on old land surfaces that have, nevertheless, been widely used globally and in northern New Zealand for productive agriculture and horticulture. The Kainui soil in the northern Hamilton lowlands and adjacent regions (in northern North Island) occurs on flattish summits, shoulders and backslopes on gently-rolling hills or terraces of an old, Mid-Quaternary paleo-landscape. It comprises a two-storeyed, tephra-derived Ultisol of Late Quaternary age with the upper part, a silt-rich coverbed c. $0.6 \mathrm{~m}$ in thickness on average, formed from multiple, thin, intermixed, mainly rhyolitic tephras $\leq$ c. $50 \mathrm{ka}$, and a lower part comprising a buried clay-rich paleosol formed from much older, strongly weathered tephra (Hamilton Ash). Because the Kainui's soil's accumulating (composite) parent materials are diachronous, the age of the soil cannot be enunciated as a single number; rather, an age range is required.

(2) Although much intermixing has occurred through developmental upbuilding pedogenesis (including via bioturbation), the upper part of the coverbed is inferred to comprise mainly post-20-ka tephras, numerous in number (c. 40 macroscopic beds) but relatively thin (mostly in the millimetre to centimetre range) as identified in sediments in lakes adjacent to the hills; the lower part consists chiefly of pre-20-ka tephras (in the centimetre to decimetre thickness range) including Okareka (c. 21.8 ka), Kawakawa (c. 25.4 ka), Okaia (c. $28.6 \mathrm{ka}$ ) (newly identified in this study), Tāhuna (c. $39.3 \mathrm{ka}$ ) and Rotoehu (c. $50 \mathrm{ka}$ ), the last easily the thickest (c. $25 \mathrm{~cm}$ thick) in the coverbed deposits (Figure 5). The age of the basal part of the coverbed (c. $50 \mathrm{ka}$ ) was derived using tephrochronology by characterising and identifying Rotoehu Ash largely via its diagnostic cummingtonite-rich ferromagnesian mineral assemblage.

(3) The coverbed unconformably overlies the lower part, a buried clay-rich paleosol formed on strongly weathered clay-rich tephras (upper Hamilton Ash) containing relict argillans (clay skins) that probably formed in the Last Interglacial. The lower buried paleosol, >c. $50 \mathrm{ka}$ in age, is otherwise not dated directly. An age of c. $125 \mathrm{ka}$ (MOIS 5e) is inferred using climatostratigraphy from the physical and clay mineralogical properties of welded paleosols in the underlying c. 3-m-thick Hamilton Ash sequence together with the presence of the c. 0.5-m-thick, 340-ka Rangitawa Tephra, deposited late in MOIS 10, at the base of the sequence. The wavy to irregular surface on top of the buried paleosol represents a tree-overturn paleo-surface with an approximate minimum age estimated at c. $74 \mathrm{ka}$ (the MOIS $5 / 4$ boundary).

(4) Both the upper and lower parts of the Kainui soil were formed by developmental upbuilding pedogenesis, providing an exemplar for this process (which is generally still not well represented in the global literature relating to soil genesis) and the key role of soil stratigraphy. The composite coverbed of tephras accumulated on the land surface at an average rate of just c. $1.2 \mathrm{~mm} /$ century, and each part of the ensuing soil has been an 'A' horizon (at the soil surface) as the land surface rose slowly. Detailed insight into the origin of the lower paleosol in Hamilton Ash is obscured by its strong alteration but this (now buried) soil is also the result of developmental upbuilding pedogenesis on the basis of micromorphological evidence for the closely related Naike soil on exhumed Hamilton Ash [17]. The entire Hamilton Ash sequence below the Kainui soil represents a composite set of clayey, welded paleosols very probably developed by upbuilding pedogenesis 
from MOIS 10 to 5 . The basal Rangitawa Tephra is underlain unconformably by a much older tephra-derived, extremely clay-rich, welded paleosol sequence on Kauroa Ash beds >c. $0.78 \mathrm{Ma}$ in age.

(5) The clay mineral assemblages of both upper and lower parts of the Kainui soil are dominated by halloysite of the kaolin subgroup. The formation of halloysite rather than allophane in the relatively 'young' ( $\leq$ c. $50 \mathrm{ka}$ ) coverbed tephras (Figure 8A) is the result of limited desilication (consistent with the Si-leaching model) as a consequence of various factors including the presence of the slowly-permeable paleosol on Hamilton Ash at shallow depths $\leq$ c. $0.8 \mathrm{~m}$ (slowing the downward movement of water and hence reducing the loss of $\mathrm{Si}$ in soil solution), the dominance of silica-rich rhyolitic tephras in the coverbed, not-infrequent soil moisture deficits extending over several months of the year, and the formation of much of the soil during MOIS 3 and 2 when rainfall was generally lower than today's. The resultant soils are invariably Ultisols.

(6) At sites in the southern Hamilton lowlands and further south in Waipa District where the greater accumulative thickness of the composite coverbed tephras $(\leq \mathrm{c} .50 \mathrm{ka})$ readily exceeds the c. $0.8 \mathrm{~m}$ threshold (Figure 1A), such as at Kakepuku Road (Figure 8B), the greater depth to the underlying paleosol on Hamilton Ash (at c. $1.5 \mathrm{~m}$ ) provides more 'room' for sufficient desilication to enable Al-rich allophane, not halloysite, to form in the upper soil above c. $0.9 \mathrm{~m}$ depth (Figure 8B). Below 0.9 m or so, marked by the c. 25.4-ka Kawakawa Tephra, mainly halloysite with some allophane was formed during the time of tephra (and minor tephric loess) accretion during MOIS 3-2 [18]. The modern Otorohanga soil is therefore an Andisol (one of the oldest in the world, taking the entire profile, c. 1 to $2 \mathrm{~m}$ deep, into account) [110]. The synthesis of allophane in the southern locations is enhanced by a higher average rainfall (increasing throughflow in the soil) and by the greater relative proportion of Al-rich andesitic tephras intermixed with the nonetheless predominantly rhyolitic tephras that make up the composite soil parent materials.

(7) The Kainui soil has been characterized previously as having an eluvial and illuvial couplet, namely a pale E horizon over a (translocated clay-enriched) Bt (argillic/kandic) horizon, forming a sequum. However, the soil stratigraphic evidence shows that the Bt horizon is a buried soil, hence is classed as a $2 \mathrm{bBt}$ horizon, with the upper boundary representing a lithologic discontinuity or unconformity. Therefore the sequum is illusory because the $\mathrm{E}$ and $(2 \mathrm{~b}) \mathrm{Bt}$ horizons are (largely) not connected genetically and are some tens of thousands of years apart in age. Most if not all of the clay skins in the $2 \mathrm{bBt}$ horizon are relict. Hence, the designation of an E horizon may be morphologically correct but genetically less so; the compromise designation as an EBw horizon, as suggested by Clayden and Hewitt [46] in situations where a lithologic discontinuity occurs, is appropriate.

(8) The revelation of contemporary perched gleying, forming an EBw $(\mathrm{g})$ horizon in the lower part of the coverbed of the Kainui soil, in early spring after a wet winter at a favourable landscape position (Figure 10A), explains the ubiquitous occurrence of $>2 \%$ redox segregations (mainly $\mathrm{MnO}_{2}$ concretions and mangans) in this juxtaposition in the Kainui soils. The relative abundance of low chroma colours is not quite sufficient for the gleyed horizon to qualify as having aquic conditions in ST (although such status would be expected to occur where the right conditions prevail).

(9) The Kainui soil at Gordonton Road and similar sites qualifies as a Typic Kandiudult in ST and, uniquely, as a Buried-granular Yellow Ultic Soil in NZSC, being the only soil in this taxonomic category in New Zealand.

(10) These conclusions above have arisen primarily through a multipronged approach based on synthesising tephrostratigraphy (of both subaerial/dryland and lacustrine deposits), tephrochronology (as a correlational and dating tool), pedology (including soil morphology, genesis and classification), paleopedology and soil stratigraphy, together with primary and secondary (clay) mineralogy. These tools have been essential in helping to elucidate the origin, age and classification of the special Kainui soil, as I hope has been demonstrated. 
Funding: This research received no external funding.

Acknowledgments: I have been thinking about the multiple aspects that inform the main thesis of this paper for more than 40 years and so it is fulfilling to integrate my earlier and more recent ideas in a modern context. Valentí Rull (Editor-in-Chief) is therefore especially thanked for encouraging me to submit the article. I also appreciated helpful and positive comments from two anonymous referees and from Helen Li. Cambridge University Press and Elsevier are thanked for permitting me to re-publish (modified) Figures 8 and 9, respectively. I also thank Paul Froggatt for analysing glass shards from sample LM3, Cath and Ed Blake for providing ongoing access to their property at Swallow Lane, Matthew House and Anne Wecking for help with profile descriptions of the Kainui soil there, Peter Singleton for his comments on the soils depicted in Figure 10, Rewi Newnham for comments on the (likely) Last Interglacial vegetation of the Hamilton Basin, Max Oulton for drawing Figures 1, 8 and 9, Wiremu Puke for advice regarding Māori names and landscape features, Seb Lowe for providing Figure 4, and Maia Kidd and Tim Ingle for help with Table 1 and Figure 6D, respectively. John Green is acknowledged for his earlier supportive role in acquiring and interpreting lake sediment cores, Alan Hogg for dating them for me using radiocarbon, and Jock Churchman, global doyen of clay mineralogy, greatly bolstered my understanding of the beguiling (clayey) allies, allophane and halloysite, of tephra-dominated terrains. Many years ago, in 1979, Phillip Tonkin alerted me to the tree-upturned nature of the paleosurface on the Hamilton Ash in the Kainui soil. He and Gary Orbell and the late John McCraw and Harry Gibbs, have been important mentors in pedology and geomorphology. The article is an output of the EXTRAS project "EXTending TephRAS as a global geoscientific research tool stratigraphically, spatially, analytically and temporally" led by the International focus group on tephrochronology and volcanism (INTAV) of the Stratigraphy and Chronology Commission (SACCOM) of the International Union for Quaternary Research (INQUA) for 2015-2019.

Conflicts of Interest: The author declares no conflict of interest.

\section{References}

1. Soil Survey Staff. Soil Taxonomy, 2nd edition. In USDA Natural Resources Conservation Service Agriculture Handbook; No. 436; United States Department of Agriculture, US Government Printing Office: Washington, DC, USA, 1999; 869p.

2. Buol, S.W.; Southard, R.J.; Graham, R.C.; McDaniel, P.A. Soil Genesis and Classification, 5th ed.; Iowa State University Press (a Blackwell Publishing Company): Ames, IA, USA, 2003; 494p.

3. Weil, R.R.; Brady, N.C. The Nature and Properties of Soils, 15th ed.; Pearson: Columbus, OH, USA, 2017; 1104p.

4. Miller, B.J. Ultisols. In Pedogenesis and Soil Taxonomy: II. The Soil Orders. Developments in Soil Science; Wilding, L.P., Smeck, N.E., Hall, G.F., Eds.; Elsevier: Amsterdam, The Netherlands, 1983; Volume 11, pp. $283-323$.

5. West, L.T.; Shaw, J.N.; Beinroth, F.H. Ultisols. In Handbook of Soil Sciences, 2nd Edition. Vol. 1: Properties and Processes; Huang, P.M., Li, Y., Sumner, M.E., Eds.; CRC Press: Boca Raton, FL, USA, 2012; pp. 33.167-33.177.

6. Wilding, L.P.; West, L.T. Introduction: General characteristics of soil orders and global distribution. In Handbook of Soil Sciences, 2nd Edition. Vol. 1: Properties and Processes; Huang, P.M., Li, Y., Sumner, M.E., Eds.; CRC Press: Boca Raton, FL, USA, 2012; pp. 33.3-33.8.

7. Lowe, D.J.; Newnham, R.M.; McCraw, J.D. Quaternary environmental change in New Zealand and its effects on the soil pattern. In Soil 2000: New Horizons for a New Century, Proceedings of the Australian E New Zealand 2nd Joint Soils Conference, Christchurch, New Zealand, 3-8 December 2000; Adams, J.A., Metherell, A.K., Eds.; New Zealand Society of Soil Science: Lincoln, New Zealand, 2000; Volume 3, pp. 117-118.

8. Rijske, W.C.; Hewitt, A.E. Soil Map of the North Island, New Zealand Soil Classification, 1: 1,000,000; Manaaki Whenua, Landcare Research: Lincoln, New Zealand, 1995.

9. Gibbs, H.S.; Cowie, J.D.; Pullar, W.A. Soils of North Island. N. Z. Soil Bur. Bull. 1968, 26-1, 48-67.

10. Lowe, D.J. Tephrochronology and its application: A review. Quat. Geochronol. 2011, 6, 107-153. [CrossRef]

11. Hewitt, A.E. New Zealand Soil Classification, 3rd ed.; Manaaki Whenua Press, Landcare Research: Lincoln, New Zealand, 2010; 136p.

12. Lowe, D.J.; Alloway, B.V. Tephrochronology. In Encyclopaedia of Scientific Dating Methods; Rink, W.J., Thompson, J.W., Eds.; Springer: Dordrecht, The Netherlands, 2015; pp. 783-799.

13. Birrell, K.S.; Pullar, W.A. Weathering of paleosols in Holocene and late Pleistocene tephras in central North Island, New Zealand. N. Z. J. Geol. Geophys. 1973, 16, 687-702. [CrossRef]

14. Lowe, D.J.; Percival, H.J. Clay mineralogy of tephras and associated paleosols and soils and hydrothermal deposits, North Island [New Zealand]. In Proceedings of the Tenth International Clay Conference, Adelaide, Australia, 18-23 July 1993.

15. Gibbs, H.S. Nature of paleosols in New Zealand and their classification. In Paleopedology_Origin, Nature and Dating of Paleosols; Yaalon, D.H., Ed.; ISSS and Israel University Press: Jerusalem, Israel, 1970; pp. 229-244. 
16. Campbell, I.B. Recognition of paleosols in Quatemary periglacial and volcanic environments in New Zealand. In Paleosols_Their Recognition and Interpretation; Wright, V.P., Ed.; Blackwell: London, UK, 1986; pp. 208-241.

17. Bakker, L.; Lowe, D.J.; Jongmans, A.G. A micromorphological study of pedogenic processes in an evolutionary soil sequence formed on Late Quaternary rhyolitic tephra deposits, North Island, New Zealand. Quat. Int. 1996, 34-36, 249-261. [CrossRef]

18. Lowe, D.J. Controls on the rates of weathering and clay mineral genesis in airfall tephras: A review and New Zealand case study. In Rates of Chemical Weathering of Rocks and Minerals; Colman, S.M., Dethier, D.P., Eds.; Academic Press: Orlando, FL, USA, 1986; pp. 265-330.

19. Lowe, D.J.; Palmer, D.J. Andisols of New Zealand and Australia. J. Integr. Field Sci. 2005, 2, $39-65$.

20. Stevens, K.F.; Vucetich, C.G. Weathering of Upper Quaternary tephras in New Zealand. 2. Clay minerals and their climatic interpretation. Chem. Geol. 1985, 53, 237-247. [CrossRef]

21. Cronin, S.J.; Neall, V.E.; Palmer, A.S. Investigation of an aggrading paleosol developed into andesitic ring-plain deposits, Ruapehu volcano, New Zealand. Geoderma 1996, 69, 119-135. [CrossRef]

22. Newnham, R.M.; Lowe, D.J.; Williams, P.W. Quaternary environmental change in New Zealand: A review. Prog. Phys. Geogr. 1999, 23, 567-610. [CrossRef]

23. Palmer, A.S. Pedostratigraphy. In The Encyclopaedia of Quaternary Science, 2nd ed.; Elias, S.A., Mock, C.J., Eds.; Elsevier: Amsterdam, The Netherlands, 2013; Volume 4, pp. 250-259.

24. Schaetzl, R.J.; Thompson, M.L. Soils—Genesis and Geomorphology, 2nd ed.; Cambridge University Press: Cambridge, UK, 2015; 778p.

25. Constatini, E.A.C. Paleosols and pedostratigraphy. Appl. Soil Ecol. 2018, 123, 597-600. [CrossRef]

26. Lowe, D.J.; Pearce, N.J.G.; Jorgensen, M.A.; Kuehn, S.C.; Tryon, C.A.; Hayward, C.L. Correlating tephras and cryptotephras using glass compositional analyses and numerical and statistical methods: review and evaluation. Quat. Sci. Rev. 2017, 175, 1-44. [CrossRef]

27. Kemp, R.A. Micromorphology of loess-paleosol sequences: A record of paleoenvironmental change. Catena 1999, 35, 179-196. [CrossRef]

28. Molloy, L.; Christie, Q. Soils in the New Zealand Landscape, 2nd ed.; New Zealand Society of Soil Science: Lincoln, New Zealand, 1998; 253p.

29. Lowe, D.J. Quaternary volcanism, tephras and tephra-derived soils in New Zealand: An introductory review. In Guidebook for Pre-Conference North Island, New Zealand "Volcanoes to Oceans" Field Tour, Proceedings of the 19th World Soils Congress, International Union of Soil Sciences, Brisbane, Australia, 27-30 July 2010; Soil and Earth Sciences Occasional Publication No. 3; Lowe, D.J., Neall, V.E., Hedley, M., Clothier, B., Mackay, A., Eds.; Massey University: Palmerston North, New Zealand, 2010; pp. 7-29.

30. Wilson, C.J.N.; Gravley, D.M.; Leonard, G.S.; Rowland, J.V. Volcanism in the central Taupo Volcanic Zone, New Zealand: Tempo, styles and controls. In Studies in Volcanology: The Legacy of George Walker; Thordarson, T., Self, S., Larsen, G., Rowland, S.K., Hoskuldsson, A., Eds.; Special Publications of IAVCEI; Geological Society: London, UK, 2009; Volume 2, pp. 225-247.

31. Shane, P.A.R. The southern end of the Pacific Ring of Fire: Quaternary volcanism in New Zealand. In Landscape and Quaternary Environmental Change in New Zealand; Shulmeister, J., Ed.; Springer/Atlantis Press: Paris, France, 2017; pp. 35-66.

32. Gibbs, H.S. Volcanic-Ash Soils of New Zealand. In New Zealand Department of Scientific and Industrial Research Information Series 65; New Zealand Department of Scientific and Industrial Research: Wellington, New Zealand, 1968; 39p.

33. Leathwick, J.; Wilson, G.; Rutledge, D.; Wardle, P.; Morgan, F.; Johnston, K.; McLeod, M.; Kirkpatrick, R. Land Environments of New Zealand; Ministry for the Environment: Wellington, New Zealand; Manaaki Whenua Landcare Research: Hamilton, New Zealand; David Bateman, Auckland, New Zealand, 2003; 184p.

34. Soil Survey Staff. Keys to Soil Taxonomy, 12th ed.; USDA Natural Resources Conservation Service: Washington, DC, USA, 2014; 360p.

35. Lowe, D.J. Origin, composite nature and pedology of late Quaternary airfall deposits, Hamilton Basin, New Zealand. Master's Thesis, University of Waikato, Hamilton, New Zealand, 1981. Unpublished.

36. Lowe, D.J. Stratigraphy, age, composition and correlation of late Quaternary tephras interbedded with organic sediments in Waikato lakes, North Island, New Zealand. N. Z. J. Geol. Geophys. 1988, 31, 125-165. [CrossRef] 
37. Lowe, D.J. Late Quaternary volcanism in New Zealand: Towards an integrated record using distal airfall tephras in lakes and bogs. J. Quat. Sci. 1988, 3, 111-120. [CrossRef]

38. Leonard, G.S.; Begg, J.G.; Wilson, C.J.N. Geology of the Rotorua Area: Scale 1: 250,000; Institute of Geological and Nuclear Sciences 1: 250,000 Geological Map 5. 99 pp. + 1 sheet; Institute of Geological and Nuclear Sciences: Lower Hutt, New Zealand, 2010.

39. Shane, P.A.R. Tephrochronology: A New Zealand case study. Earth-Sci. Rev. 2000, 49, 223-259. [CrossRef]

40. Isbell, R.F. The Australian Soil Classification; CSIRO Publishing: Melbourne, Australia, 1996; 143p.

41. McKenzie, N.; Jacquier, D.; Isbell, R.; Brown, K. Australian Soils and Landscapes—An Illustrated Compendium; CSIRO Publishing: Melbourne, Australia, 2004; 416p.

42. McCraw, J.D. The surface features and soil pattern of the Hamilton Basin. Earth Sci. J. 1967, 1, 59-74.

43. Schaetzl, R.J.; Johnston, D.L.; Burns, S.F.; Small, T.W. Tree uprooting: Review of terminology, process and environmental implications. Can. J. For. Res. 1989, 19, 1-11. [CrossRef]

44. Churchman, G.J.; Lowe, D.J. Alteration, formation and occurrence of minerals in soils. In Handbook of Soil Sciences, 2nd Edition. Vol. 1: Properties and Processes; Huang, P.M., Li, Y., Sumner, M.E., Eds.; CRC Press: Boca Raton, FL, USA, 2012; pp. 20.1-20.72.

45. Hartemink, A.E. The definition of soil since the early 1800s. Adv. Agron. 2016, 137, 73-126.

46. Clayden, B.; Hewitt, A.E. Horizon notation for New Zealand soils. Division of Land and Soil Sciences Scientific Report 1. 1989. Available online: http:/ / digitallibrary.landcareresearch.co.nz/cdm/ref/collection/ p20022coll14/id/ 69 (accessed on 5 February 2019).

47. Schoeneberger, P.J.; Wysocki, D.A.; Benham, E.C.; Soil Survey Staff. Field Book for Describing and Sampling Soils, Version 3.0.; Natural Resources Conservation Service, National Soil Survey Centre: Lincoln, NE, USA, 2012.

48. Bruce, J.G. Soils of Hamilton City, North Island, New Zealand. New Zealand Soil Survey Report 31. 65 pp. +1 sheet 1: 20,000. 1979. Available online: http:/ / digitallibrary.landcareresearch.co.nz/cdm/ref/collection/ p20022coll4/id/25 (accessed on 5 February 2019).

49. Wilson, A.D. Soils of Piako County, North Island, New Zealand. New Zealand Soil Survey Report 39. 171 pp. + 4 sheets 1: 63,360. 1980. Available online: http:/ / digitallibrary.landcareresearch.co.nz/cdm/ref/collection/ p20022coll4/id/35 (accessed on 5 February 2019).

50. McLeod, M. Soils of the Waikato lowlands. New Zealand Soil Bureau District Office Report HN 11. 32 pp. +2 sheets 1: 31,680. 1984. Available online: http:/ / digitallibrary.landcareresearch.co.nz/cdm/ref/collection/ p20022coll7/id/84 (accessed on 5 February 2019).

51. McLeod, M. Soils of the Hauraki Plains County, North Island, New Zealand. In New Zealand Department of Scientific and Industrial Research Land Resources Scientific Report 31; 162 pp. + 1 sheet 1: 50,000; 1992. Available online: https: / catalogue.data.govt.nz/dataset/soil-survey-of-hauraki-plains-county (accessed on 5 February 2019).

52. Webb, T.H.; Lilburne, L.R. Criteria for Defining the Soil Family and Soil Sibling — The Fourth and Fifth Categories of the New Zealand Soil Classification, 2nd ed.; Landcare Research Science: Lincoln, New Zealand, 2011; 38p.

53. S-map Online: The Digital Soil Map for New Zealand. Available online: https://smap.landcareresearch.co. nz/ (accessed on 5 February 2019).

54. Parfitt, R.L.; Russell, M.; Orbell, G.E. Weathering sequence of soils from volcanic ash involving allophane and halloysite, New Zealand. Geoderma 1983, 29, 41-57. [CrossRef]

55. Lowe, D.J. Stop 2 Kainui silt loam and Naike clay, Gordonton Road. In Guidebook for Pre-conference North Island Field Trip A1 "Ashes to Issues", Proceedings of the Australian and New Zealand 4th Joint Soils Conference, Massey University, Palmerston North, New Zealand, 28-30 November 2000; Lowe, D.J., Ed.; New Zealand Society of Soil Science: Lincoln, New Zealand, 2008; pp. 55-72.

56. Kear, D.; Schofield, J.C. Geology of the Ngaruawahia Subdivision. N. Z. Geol. Sur. Bull. 1978, 88, 1-168.

57. Selby, M.J.; Lowe, D.J. The middle Waikato Basin and hills. In Landforms of New Zealand, 2nd ed.; Soons, J.M., Selby, M.J., Eds.; Longman Paul: Auckland, New Zealand, 1992; pp. 233-255.

58. Edbrooke, S. (Compiler) Geology of the Waikato Area. Scale 1: 250,000. Geological Map 4. IGNS, Lower Hutt. 68 pp. +1 sheet 1: 250,000. 2005. Available online: https://www.gns.cri.nz/Home/Our-Science/ Earth-Science/Regional-Geology/Geological-Maps/1-250-000-Geological-Map-of-New-Zealand-QMAP / Digital-Data-and-Downloads (accessed on 5 February 2019). 
59. Lowe, D.J. Introduction to the landscapes and soils of the Hamilton Basin. In Guidebook for Pre-conference North Island, New Zealand "Volcanoes to Oceans" Field Tour, Proceedings of the 19th World Soils Congress, International Union of Soil Sciences, Brisbane, Australia, 27-30 July 2010; Lowe, D.J., Neall, V.E., Hedley, M., Clothier, B., Mackay, A., Eds.; Soil and Earth Sciences Occasional Publication 3; Massey University: Palmerston North, New Zealand, 2010; pp. 1.24-1.61.

60. McCraw, J.D. The wandering river-Landforms and geological history of the Hamilton Basin. In Geoscience Society of New Zealand Guidebook 16; Geoscience Society of New Zealand: Wellington, New Zealand, 2011; $88 \mathrm{p}$.

61. Ward, W.T. Volcanic ash beds in the lower Waikato Basin, North Island, New Zealand. N. Z. J. Geol. Geophys. 1967, 10, 1109-1135. [CrossRef]

62. Ruhe, R.V.; Hall, R.D.; Canepa, A.P. Sangamon paleosols of southwestern Indiana, USA. Geoderma 1974, 12, 191-200. [CrossRef]

63. Markewich, H.W.; Wysocki, D.A.; Pavich, M.J.; Rutledge, E.M. Age, genesis and paleoclimatic interpretation of the Sangamon/Loveland complex in the Lower Mississippi Valley, USA. Geol. Soc. Am. Bull. 2011, 123, 21-39. [CrossRef]

64. Pain, C.F. Some tephra deposits in the south-west Waikato area, North Island, New Zealand. N. Z. J. Geol. Geophys. 1975, 18, 541-550. [CrossRef]

65. Lowe, D.J.; Tippett, J.M.; Kamp, P.J.J.; Liddell, I.J.; Briggs, R.M.; Horrocks, J.L. Ages on weathered Plio-Pleistocene tephra sequences, western North Island, New Zealand. Les Dossiers de l'Archeo-Logis 2001, 1, 45-60.

66. Lowe, D.J.; Briggs, R.M. Age of the Kauroa Ash Formation, western North Island and some implications for palaeopedology. In Proceedings of the New Zealand Society of Soil Science Conference, Nelson, New Zealand, 21-25 November 1988; pp. 18-19.

67. Salter, R.T. A pedological study of the Kauroa Ash Formation at Woodstock. Master's Thesis, University of Waikato, Hamilton, New Zealand, 1979. Unpublished.

68. Kirkman, J.H. Mineralogy of the Kauroa Ash Formation of southwest and west Waikato, North Island, New Zealand. N. Z. J. Geol. Geophys. 1980, 23, 113-120. [CrossRef]

69. Horrocks, J.L. Stratigraphy, chronology and correlation of the Plio-Pleistocene (c. 2.2-0.8 Ma) Kauroa Ash sequence, western North Island, New Zealand. Ph.D. Thesis, University of Waikato, Hamilton, New Zealand, 2000. Unpublished.

70. Mark, D.F.; Renne, P.R.; Dymock, R.; Smith, V.C.; Simon, J.I.; Morgan, L.E.; Staff, R.A.; Elli, B.S. High-precision ${ }^{40} \mathrm{Ar} /{ }^{39} \mathrm{Ar}$ dating of Pleistocene tuffs and temporal anchoring of the Matuyama-Brunhes boundary. Quat. Geochronol. 2017, 39, 1-23. [CrossRef]

71. Briggs, R.M.; Itaya, T.; Lowe, D.J.; Keane, A.J. Ages of the Pliocene-Pleistocene Alexandra and Ngatutura Volcanics, western North Island, New Zealand and some geological implications. N. Z. J. Geol. Geophys. 1989, 32, 417-427. [CrossRef]

72. Briggs, R.M.; Lowe, D.J.; Goles, G.G.; Shepherd, T.G. Intra-conference tour day 1: Hamilton-RaglanHamilton. In Conference Tour Guides, Proceedings of the International Inter-INQUA Field Conference on Tephrochronology, Loess and Paleopedology, University of Waikato, Hamilton, New Zealand, 7-12 February 1994; Lowe, D.J., Ed.; University of Waikato: Hamilton, New Zealand, 1994; pp. 24-44.

73. Chappell, P.R. The Climate and Weather of Waikato; The National Institute of Water and Atmospheric Research (NIWA): Auckland, New Zealand, 2013; 40p.

74. Lowe, D.J. Application of impulse radar to continuous profiling of tephra-bearing lake sediments and peats: An initial evaluation. N. Z. J. Geol. Geophys. 1985, 28, 667-674. [CrossRef]

75. Green, J.D.; Lowe, D.J. Stratigraphy and development of c. 17,000 year old Lake Maratoto, North Island, New Zealand, with some inferences about postglacial climatic change. N. Z. J. Geol. Geophys. 1985, 28, 675-699. [CrossRef]

76. Lowe, D.J.; Blaauw, M.; Hogg, A.G.; Newnham, R.M. Ages of 24 widespread tephras erupted since 30,000 years ago in New Zealand, with re-evaluation of the timing and palaeoclimatic implications of the late-glacial cool episode recorded at Kaipo bog. Quat. Sci. Rev. 2013, 74, 170-194. [CrossRef]

77. Newnham, R.M.; Dirks, K.M.; Samaranayake, D. An investigation into long-distance health impacts of the 1996 eruption of Mt Ruapehu, New Zealand. Atmos. Environ. 2010, 44, 1568-1578. [CrossRef] 
78. Gehrels, M.J.; Lowe, D.J.; Newnham, R.M.; Hogg, A.G. Enhanced record of tephra fallout since 232 AD revealed by cryptotephra studies at Moanatuatua bog near Hamilton: implications for volcanic hazard analysis. (Abstract). Geosci. Soc. N. Z. Misc. Publ. 2010, 129A, 103.

79. Loame, R.C.; Lowe, D.J.; Pittari, A.; Davies, S.M.; Magill, C.R.; Vandergoes, M.J.; Rees, A.B.H.; Ross, N. Using CT scanning for reconnaissance and detection of cryptotephras in $\sim 22,000$-yr-old lake sediments, central Waikato region, New Zealand. In Proceedings of the Crossing New Frontiers: INTAV International Field Conference on Tephrochronology, 'Tephra Hunt in Transylvania', Moieciu de Sus, Romania, 24 June-1 July 2018; Hambach, U., Veres, D., Eds.; Book of Abstracts. pp. 41-42.

80. Smith, V.C.; Shane, P.A.R. Geochemical characteristics of the widespread Tahuna Tephra. N. Z. J. Geol. Geophys. 2002, 45, 103-107. [CrossRef]

81. Smith, V.C.; Shane, P.A.R.; Nairn, I.A. Trends in rhyolite geochemistry, mineralogy and magma storage during the last $50 \mathrm{kyr}$ at Okataina and Taupo volcanic centres, Taupo Volcanic Zone, New Zealand. J. Volcanol. Geotherm. Res. 2005, 148, 372-406. [CrossRef]

82. Molloy, C.; Shane, P.A.R.; Augustinus, P.C. Eruption recurrence rates in a basaltic volcanic field based on tephra layers in maar sediments: implications for hazards in the Auckland volcanic field. Geol. Soc. Am. Bull. 2009, 121, 1666-1677. [CrossRef]

83. Froggatt, P.C.; Lowe, D.J. A review of late Quaternary silicic and some other tephra formations from New Zealand: Their stratigraphy, nomenclature, distribution, volume and age. N. Z. J. Geol. Geophys. 1990, 33, 89-109. [CrossRef]

84. Danišík, M.; Shane, P.A.R.; Schmitt, A.K.; Hogg, A.G.; Santos, G.M.; Storm, S.; Evans, N.J.; Fifield, L.K.; Lindsay, J.M. Re-anchoring the late Pleistocene tephrochronology of New Zealand based on concordant radiocarbon ages and combined ${ }^{238} \mathrm{U} /{ }^{230} \mathrm{Th}$ disequilibrium and (U-Th)/He zircon ages. Earth Planet. Sci. Lett. 2012, 349-350, 240-250. [CrossRef]

85. Newnham, R.M.; Lowe, D.J.; Green, J.D.; Turner, G.M.; Harper, M.A.; McGlone, M.S.; Stout, S.L.; Horie, S.; Froggatt, P.C. A discontinuous ca. 80 ka record of Late Quaternary environmental change from Lake Omapere, Northland, New Zealand. Palaeogeogr. Palaeoclimatol. Palaeoecol. 2004, 207, 165-198. [CrossRef]

86. Flude, S.; Storey, M. ${ }^{40} \mathrm{Ar} /{ }^{39} \mathrm{Ar}$ age of the Rotoiti Breccia and Rotoehu Ash, Okataina Volcanic Complex, New Zealand and identification of heterogeneously distributed excess ${ }^{40} \mathrm{Ar}$ in supercooled crystals. Quat. Geochronol. 2016, 33, 13-23. [CrossRef]

87. Howorth, R.; Froggatt, P.C.; Vucetich, C.G.; Collen, J.D. Editorial in “Proceedings of a Tephra Workshop, 30 June-1 July 1980, Victoria University of Wellington. Publ. Geol. Dep. Vic. Univ. Wellingt. 1981, 20, 1-4.

88. Jurado-Chichay, Z.; Walker, G.P.L. Stratigraphy and dispersal of the Mangaone Subgroup pyroclastic deposits, Okataina Volcanic Centre, New Zealand. J. Volcanol. Geotherm. Res. 2000, 104, 319-383. [CrossRef]

89. Hogg, A.G.; Lowe, D.J.; Hendy, C.H. University of Waikato radiocarbon dates I. Radiocarbon 1987, $29,263-301$. [CrossRef]

90. Vandergoes, M.J.; Hogg, A.G.; Lowe, D.J.; Newnham, R.M.; Denton, G.H.; Southon, J.; Barrell, D.J.A.; Wilson, C.J.N.; McGlone, M.S.; Allan, A.S.R.; et al. A revised age for the Kawakawa/Oruanui tephra, a key marker for the Last Glacial Maximum in New Zealand. Quat. Sci. Rev. 2013, 74, 195-201. [CrossRef]

91. Lowe, D.J.; Rees, A.B.H.; Newnham, R.M.; Hazell, Z.J.; Gehrels, M.J.; Charman, D.J.; Amesbury, M.J. Isochron-informed Bayesian age modelling for tephras and cryototephras: Application to mid-Holocene Tuhua tephra, northern New Zealand. In Proceedings of the Crossing New Frontiers: INTAV International Field Conference on Tephrochronology, 'Tephra Hunt in Transylvania', Moieciu de Sus, Romania, 24 June-1 July 2018; Hambach, U., Veres, D., Eds.; Book of Abstracts. pp. 95-96.

92. Lowe, D.J.; Shane, P.A.R.; Alloway, B.V.; Newnham, R.M. Fingerprints and age models for widespread New Zealand tephra marker beds erupted since 30,000 years ago: A framework for NZ-INTIMATE. Quat. Sci. Rev. 2008, 27, 95-126. [CrossRef]

93. Vucetich, C.G.; Howorth, R. Late Pleistocene tephrostratigraphy in the Taupo district, New Zealand. N. Z. J. Geol. Geophys. 1976, 19, 51-69. [CrossRef]

94. Wilson, C.J.N. The 26.5 ka Oruanui eruption, New Zealand: An introduction and overview. J. Volcanol. Geotherm. Res. 2001, 112, 133-174. [CrossRef] 
95. Pullar, W.A. Maps of isopachs and volumes of tephra, central North Island, New Zealand, 1: 1,000,000 (2 sheets). 1972. New Zealand Soil Survey Report 1. Pullar, W.A., Birrell, K.S., Eds.; 32 pp. + Multiple Sheets. Age and Distribution of Late Quaternary Pyroclastic and Associated Cover Deposits of the Rotorua and Taupo Area, North Island, New Zealand. 1973. Available online: https://soils.landcareresearch.co.nz/ assets /Soil-maps/SB-133-1-7.pdf (accessed on 19 February 2019).

96. Vucetich, C.G.; Pullar, W.A. Stratigraphy and chronology of late Pleistocene volcanic ash beds in central North Island, New Zealand. N. Z. J. Geol. Geophys. 1969, 12, 784-837. [CrossRef]

97. Hogg, A.G.; McCraw, J.D. Late Quaternary tephras of Coromandel Peninsula, North Island, New Zealand: A mixed peralkaline and calcalkaline tephra sequence. N. Z. J. Geol. Geophys. 1983, 26, 163-187. [CrossRef]

98. Hogg, A.G.; Lowe, D.J.; Palmer, J.G.; Boswijk, G.; Bronk Ramsey, C.J. Revised calendar date for the Taupo eruption derived by ${ }^{14} \mathrm{C}$ wiggle-matching using a New Zealand kauri ${ }^{14} \mathrm{C}$ calibration data set. Holocene 2012, 22, 439-449. [CrossRef]

99. Tonkin, P.J. Note on the occurrence of Taupo Pumice in the Hamilton Basin. Earth Sci. J. 1967, 1, 31-32.

100. Lian, O.B.; Shane, P.A.R. Optical dating of paleosols bracketing the widespread Rotoehu tephra, North Island, New Zealand. Quat. Sci. Rev. 2000, 19, 1649-1662. [CrossRef]

101. Schmitz, M.D.; Smith, I.E.M. The petrology of the Rotoiti eruption sequence, Taupo Volcanic Zone: An example of fractionation and mixing in a rhyolitic system. J. Petrol. 2004, 45, 2045-2066. [CrossRef]

102. McGlone, M.S.; Howorth, R.; Pullar, W.A. Late Pleistocene stratigraphy, vegetation and climate of the Bay of Plenty and Gisborne regions, New Zealand. N. Z. J. Geol. Geophys. 1984, 27, 327-350.

103. Froggatt, P.C.; Gosson, G.J. Techniques for the preparation of tephra samples for mineral and chemical analysis and radiometric dating. Publ. Geol. Dep. Vic. Univ. Wellingt. 1982, 23, 1-12.

104. Froggatt, P.C. Toward a comprehensive Upper Quatemary tephra and ignimbrite stratigraphy in New Zealand using electron microprobe analysis of glass shards. Quat. Res. 1983, 19, 188-200. [CrossRef]

105. Jarosewich, E.; Nelen, J.A.; Norberg, J.A. Reference samples for electron microprobe analysis. Geostand. Newslett. 1980, 4, 43-47. [CrossRef]

106. Stokes, S.; Lowe, D.J.; Froggatt, P.C. Discriminant function analysis and correlation of late Quaternary rhyolitic tephra deposits from Taupo and Okataina volcanoes, New Zealand, using glass shard major element composition. Quat. Int. 1992, 13-14, 103-117. [CrossRef]

107. Alloway, B.V.; Lowe, D.J.; Larsen, G.; Shane, P.A.R.; Westgate, J.A. Tephrochronology. In The Encyclopaedia of Quaternary Science, 2nd ed.; Elias, S.A., Mock, C.J., Eds.; Elsevier: Amsterdam, The Netherlands, 2013; Volume 4, pp. 277-304.

108. Pullar, W.A. Volcanic ash beds in the Waikato District. Earth Sci. J. 1967, 1, 17-30.

109. Lowe, D.J. Kainui silt loam: How the leopard changed its spots. N. Z. Soil News 1991, 39, 161-163.

110. McDaniel, P.A.; Lowe, D.J.; Arnalds, O.; Ping, C.-L. Andisols. In Handbook of Soil Sciences, 2 nd Edition. Vol. 1: Properties and Processes; Huang, P.M., Li, Y., Sumner, M.E., Eds.; CRC Press: Boca Raton, FL, USA, 2012; pp. 33.29-33.48.

111. Lowe, D.J.; Tonkin, P.J. Unravelling upbuilding pedogenesis in tephra and loess sequences in New Zealand using tephrochronology. In Proceedings of the 19th World Congress of Soil Science "Soil Solutions for a Changing World", Brisbane, Australia, 1-6 August 2010; Symposium 1.3.2 Geochronological Techniques and Soil Formation. 2010; pp. 34-37. Available online: https://iuss.org/19th\%20WCSS/Symposium/pdf/0116. pdf (accessed on 5 February 2019).

112. Inoue, Y.; Hiradate, S.; Sase, T.; Hosono, M.; Morita, S.; Matsuzaki, H. Using ${ }^{14} \mathrm{C}$ dating of stable humin fractions to assess upbuilding pedogenesis of a buried Holocene humic soil horizon, Towada volcano, Japan. Geoderma 2011, 167-168, 85-90. [CrossRef]

113. Lowe, D.J.; Tonkin, P.J.; Palmer, J.; Lanigan, K.; Palmer, A.S. Dusty horizons. In A Continent on the Move: New Zealand Geoscience Revealed, 2nd ed.; Graham, I., Ed.; GSNZ Miscellaneous Publication 141; Geoscience Society of New Zealand with GNS Science: Wellington, New Zealand, 2015; pp. 286-289.

114. Alloway, B.V.; Almond, P.C.; Moreno, P.J.; Sagredo, E.; Kaplan, M.R.; Kubik, P.W.; Tonkin, P.J. Mid-latitude trans-Pacific reconstructions and comparisons of coupled glacial/interglacial climate cycles based on soil stratigraphy of cover-beds. Quat. Sci. Rev. 2018, 189, 57-75. [CrossRef]

115. Muhs, D.R.; McGeehin, J.P.; Beann, J.; Fisher, E. Holocene loess deposition and soil formation as competing processes, Matanuska Valley, southern Alaska. Quat. Res. 2004, 61, 265-276. [CrossRef] 
116. Kemp, R.A.; Derbyshire, E.; Xingmin, M. Micromorphological variation of the S1 paleosol across northwest China. Catena 1997, 31, 77-90. [CrossRef]

117. Kemp, R.A.; Derbyshire, E. The loess soils of China as records of climate change. Eur. J. Soil Sci. 1998, 49, 525-539. [CrossRef]

118. Jacobs, P.M.; Mason, J.A. Late Quaternary climate change, loess sedimentation and soil profile development in the central Great Plains: A pedosedimentary model. Geol. Soc. Am. Bull. 2007, 119, 462-475. [CrossRef]

119. Leonard, G.; Lowe, D.J.; McSaveney, E.; Smith, R.T.; Stewart, C.; Wright, I. Living on the ring of fire-Volcanoes. In Life on the Edge-New Zealand's Natural Hazards and Disasters; Te Ara staff, Ed.; David Bateman: Auckland, New Zealand, 2007; pp. 76-115.

120. Lowe, D.J.; Lanigan, K.M.; Palmer, D.J. Where geology meets pedology: Late Quaternary tephras, loess and paleosols in the Mamaku Plateau and Lake Rerewhakaaitu areas. In Field Trip Guides, Geosciences 2012 Conference, Hamilton, New Zealand; Geoscience Society of New Zealand Miscellaneous Publication 134B; Pittari, A., Ed.; (compiler); Geoscience Society of New Zealand: Wellington, New Zealand, 2012; pp. 2.1-2.45.

121. Morrison, R.B. How can the treatment of pedostratigraphic units in the North American Stratigraphic Code be improved? Quat. Int. 1998, 51-52, 30-33. [CrossRef]

122. North American Commission on Stratigraphic Nomenclature, North American Stratigraphic Code. Am. Assoc. Petrol. Geol. Bull. 2005, 89, 1547-1591.

123. Paton, T.R.; Humphreys, G.S.; Mitchell, P.B. Soils: A New Global View; UCL Press: London, UK, 1995; 213p.

124. Almond, P.C.; Tonkin, P.J. Pedogenesis by upbuilding in an extreme leaching and weathering environment and slow loess accretion, south Westland, New Zealand. Geoderma 1999, 92, 1-36. [CrossRef]

125. Johnson, D.L.; Watson-Stegner, D. Evolution model of pedogenesis. Soil Sci. 1987, 143, 349-366. [CrossRef]

126. Johnson, D.L.; Watson-Stegner, D.; Johnson, D.N.; Schaetzl, R.J. Proisotropic and proanisotropic processes of pedoturbation. Soil Sci. 1987, 143, 278-292. [CrossRef]

127. Johnson, D.L.; Keller, E.A.; Rockwell, T.K. Dynamic pedogenesis: New views on some key soil concepts and a model for interpreting Quaternary soils. Quat. Res. 1990, 33, 306-319. [CrossRef]

128. Lowe, D.J. Upbuilding pedogenesis in multisequal tephra-derived soils in the Waikato region. In Soil 2000: New Horizons for a New Century, Proceedings of the Australian and New Zealand 2nd Joint Soils Conference, Canterbury, UK, 3-8 December 2000; Adams, J.A., Metherell, A.K., Eds.; New Zealand Society of Soil Science: Lincoln, New Zealand, 2000; Volume 2, pp. 183-184.

129. Eden, D.N.; Hammond, A.P. Dust accumulation in the New Zealand region since the last glacial maximum. Quat. Sci. Rev. 2003, 22, 2037-2052. [CrossRef]

130. Lowe, D.J. The time machine. Norman Taylor Memorial Lecture 2002. N. Z. Soil News 2002, 50, $124-135$.

131. Cunningham, M.J.; Lowe, D.J.; Wyatt, J.B.; Moon, V.G.; Churchman, G.J. Discovery of halloysite books in altered silicic Quaternary tephras, northern New Zealand. Clay Miner. 2016, 51, 351-372. [CrossRef]

132. Schaetzl, R.J.; Sorenson, C.J. The concept of "buried" versus "isolated" paleosols: Examples from northeastern Kansas. Soil Sci. 1987, 143, 426-435. [CrossRef]

133. Johnson, D.L. Paleosols are buried soils. Quat. Int. 1998, 51/52, 7. [CrossRef]

134. Lowe, D.J. Teaching clays: From ashes to allophane. In Clays: Controlling the Environment, Proceedings of the 10th International Clay Conference, Adelaide, Australia, 18-23 July 1993; Churchman, G.J., Fitzpatrick, R.W., Eggleton, R.A., Eds.; CSIRO Publishing: Melbourne, Australia, 1995; pp. 19-23.

135. Huang, Y.-T.; Lowe, D.J.; Churchman, G.J.; Schipper, L.A.; Cursons, R.; Zhang, H.; Chen, T.-Y.; Cooper, A. DNA adsorption by nanocrystalline allophane spherules and nanoaggregates and implications for carbon sequestration in Andisols. Appl. Clay Sci. 2016, 120, 40-50. [CrossRef]

136. New Zealand Soil Bureau. Soils of New Zealand, Part 3. N. Z. Soil Bur. Bull. 1968, 26-3, 1-126.

137. Taylor, N.H.; Pohlen, I.J. Soil Survey Method: A New Zealand Handbook for the Field Study of Soils, amended edition. In New Zealand Soil Bureau Bulletin 25; New Zealand Dept. of Scientific and Industrial Research: Wellington, New Zealand, 1970; 242p.

138. Hochella, M.F., Jr. Nanogeoscience: From origins to cutting-edge applications. Elements 2008, 4, 373-379. [CrossRef]

139. Theng, B.K.G. Clay Mineral Catalysis of Organic Reactions; CRC Press (Taylor and Francis): Boca Raton, FL, USA, 2019; 425p.

140. Parfitt, R.L.; Saigusa, M.; Cowie, J.D. Allophane and halloysite formation in a volcanic ash bed under differing moisture conditions. Soil Sci. 1984, 138, 360-364. [CrossRef] 
141. Singleton, P.L.; Mcleod, M.; Percival, H.J. Allophane and halloysite content and soil solution silicon in soils from rhyolitic volcanic material, New Zealand. Aust. J. Soil Res. 1989, 27, 67-77. [CrossRef]

142. Parfitt, R.L. Soils formed in tephra in different climatic regions. In Proceedings of the Transactions, XIV Congress of the International Society of Soil Science, Kyoto, Japan, 12-18 August 1990; Volume VII, pp. 134-139.

143. Parfitt, R.L.; Wilson, A.D. Estimation of allophane and halloysite in three sequences of volcanic soils in New Zealand. Catena Suppl. 1985, 7, 1-8.

144. Parfitt, R.L. Allophane and imogolite: Role in soil biogeochemical processes. Clay Miner. 2009, 44, $135-155$. [CrossRef]

145. Hodder, A.P.W.; Green, B.E.; Lowe, D.J. A two-stage model for the formation of clay minerals from tephra-derived volcanic glass. Clay Miner. 1990, 25, 313-327. [CrossRef]

146. Vacca, A.; Adamo, P.; Pigna, M.; Violante, P. Genesis of tephra-derived soils from the Roccamonfina volcano, south central Italy. Soil Sci. Soc. Am. J. 2003, 67, 198-207. [CrossRef]

147. Alloway, B.V.; Neall, V.E.; Vucetich, C.G. Particle size analyses of late Quaternary allophane-dominated andesitic deposits from New Zealand. Quat. Int. 1992, 13-14, 167-174. [CrossRef]

148. Churchman, G.J.; Pontifex, I.R.; McClure, S.G. Factors affecting the formation and characteristics of halloysites or kaolinites in granitic and tuffaceous saprolites in Hong Kong. Clays Clay Miner. 2010, 58, 220-237. [CrossRef]

149. Moon, V.G.; Lowe, D.J.; Cunningham, M.J.; Wyatt, J.; Churchman, G.J.; de Lange, W.P.; Mörz, T.; Kreiter, S.; Kluger, M.O.; Jorat, M.E. Sensitive pyroclastic-derived halloysitic soils in northern New Zealand: Interplay of microstructure, minerals and geomechanics. In Volcanic Rocks and Soils, Proceedings of the International Workshop on Volcanic Rocks and Soils, Lacco Ameno, Ischia Island, Italy, 24-25 September 2015; Rotonda, T., Cecconi, M., Silvestri, F., Tommasi, P., Eds.; Taylor and Francis: London, UK, 2015; pp. 3-21.

150. de Lisle, J.F. The climate of the Waikato Basin. Earth Sci. J. 1967, 1, 2-16.

151. McLeod, M. Soils of the proposed Te Kawa irrigation scheme. In New Zealand Soil Bureau District Office Report HN 10; Department of Scientific and Industrial Research: Wellington, New Zealand, 1984; 57p.

152. Barratt, B.C. Soils of Part Otorohanga County, North Island, New Zealand. In New Zealand Soil Survey Report 62; 64 pp. + 1 sheet 1: 50,000; Department of Scientific and Industrial Research: Wellington, New Zealand, 1981.

153. Lorrey, A.M.; Bostock, H. The climate of New Zealand through the Quaternary. In Landscape and Quaternary Environmental Change in New Zealand; Shulmeister, J., Ed.; Springer/Atlantis Press: Paris, France, 2017; pp. 67-139.

154. Eaves, S.R.; Mackintosh, A.N.; Anderson, B.M.; Doughty, A.M.; Townsend, D.B.; Conway, C.E.; Winckler, G.; Schaefer, J.M.; Leonard, G.S.; Calvert, A.T. The Last Glacial Maximum in the central North Island, New Zealand: Paleoclimate inferences from glacier modelling. Clim. Past 2016, 12, 943-960. [CrossRef]

155. Barrell, D.J.A.; Almond, P.C.; Vandergoes, M.J.; Lowe, D.J.; Newnham, R.M.; NZ-INTIMATE members. A composite pollen-based stratotype for inter-regional evaluation of climatic events in New Zealand over the past 30,000 years (NZ-INTIMATE project). Quat. Sci. Rev. 2013, 74, 4-20. [CrossRef]

156. Hendy, C.H.; Wilson, A.T. Palaeoclimate data from speleothems. Nature 1968, 219, 48-51. [CrossRef]

157. Whittaker, T.E.; Hendy, C.H.; Hellstrom, J.C. Abrupt millennial-scale changes in intensity of Southern Hemisphere westerly winds during marine isotope stages 2-4. Geology 2011, 39, 455-458. [CrossRef]

158. Wada, K. Minerals formed and mineral formation from volcanic ash by weathering. Chem. Geol. 1987, 60, 17-28. [CrossRef]

159. Shikazono, N.; Takino, A.; Ohtani, H. An estimate of dissolution rate constant of volcanic glass in volcanic ash soil from the Mt. Fuji area, central Japan. Geochem. J. 2005, 39, 185-196. [CrossRef]

160. Ildefonse, P.; Kirkpatrick, R.J.; Montez, B.; Calas, G.; Flank, A.M.; Lagarde, P. ${ }^{27}$ Al.MAS NMR and aluminium X-ray absorption near edge structure study of imogolite and allophanes. Clays Clay Miner. 1994, 42, 276-287. [CrossRef]

161. Hiradate, S.; Wada, S.-I. Weathering processes of volcanic glass to allophane determined by ${ }^{27} \mathrm{Al}$ and ${ }^{29} \mathrm{Si}$ solid-state NMR. Clays Clay Miner. 2005, 53, 401-408. [CrossRef]

162. Churchman, G.J.; Pasbakhsh, P.; Lowe, D.J.; Theng, B.K.G. Unique but diverse: Some observations on the formation, structure and morphology of halloysite. Clay Miner. 2016, 51, 395-416. [CrossRef]

163. Milne, D.; Clayden, B.; Singleton, P.; Wilson, A. Soil Description Handbook, Revised Edition; Manaaki Whenua Press, Landcare Research: Lincoln, New Zealand, 1995; p. 157.

164. Taylor, N.H.; Pohlen, I.J. Classification of New Zealand soils. N. Z. Soil Bur. Bull. 1968, 26, 15-46. 
165. Fieldes, M.; Perrott, K.W. The nature of allophane in soils. Part 3. Rapid field and laboratory test for allophane. N. Z. J. Sci. 1966, 9, 623-629.

166. Soil Survey Staff. Buried soils and their effect on taxonomic classification. In Soil Survey Technical Note 10; USDA Natural Resources Conservation Service: Lincoln, NE, USA, 2014. Available online: https:/ / www.nrcs. usda.gov/wps/portal/nrcs/detail/tx/soils/?cid=nrcs142p2_053568 (accessed on 5 February 2019).

167. Singleton, P.L. Soils of Ruakura-A Window on the Waikato. In New Zealand Department of Scientific and Industrial Research Land Resources Scientific Report 5; 127 pp. + 1 sheet 1:5000; DSIR Land Resources: Wellington, New Zealand, 1991.

168. Birkeland, P.W. Soils and Geomorphology, 3rd ed.; Oxford University Press: New York, NY, USA, 1999; 429p.

169. Bouma, J. Hydrology and genesis of soils with aquic moisture regimes. In Pedogenesis and Soil Taxonomy: I. Concepts and Interactions; Wilding, L.P., Smeck, N.E., Hall, G.F., Eds.; Developments in Soil Science; Elsevier: Amsterdam, The Netherlands, 1983; Volume 11, pp. 253-281.

170. Wilson, C.J.N. Supereruptions and supervolcanoes: Processes and products. Elements 2008, 4, 29-34. [CrossRef]

171. Kohn, B.P.; Pillans, B.J.; McGlone, M.S. Zircon fission track age for middle Pleistocene Rangitawa Tephra, New Zealand: Stratigraphic and palaeoclimatic significance. Palaeogeogr. Palaeoclimatol. Palaeoecol. 1992, 95, 73-94. [CrossRef]

172. Pillans, B.J.; Kohn, B.P.; Berger, G.W.; Froggatt, P.C.; Duller, G.; Alloway, B.V.; Hesse, P. Multi-method dating comparison for mid-Pleistocene Rangitawa Tephra, New Zealand. Quat. Sci. Rev. 1996, 15, 1-14. [CrossRef]

173. Farley, K.A.; Kohn, B.P.; Pillans, B. The effects of secular disequilibrium on (U-Th)/He systematics and dating of Quaternary volcanic zircon and apatite. Earth Planet. Sci. Lett. 2002, 201, 117-125. [CrossRef]

174. Holt, K.; Wallace, R.C.; Neall, V.E.; Kohn, B.P.; Lowe, D.J. Quaternary tephra marker beds and their potential for palaeoenvironmental reconstruction on Chatham Islands east of New Zealand, southwest Pacific Ocean. J. Quat. Sci. 2010, 25, 1169-1178. [CrossRef]

175. Matthews, N.E.; Smith, V.C.; Costa, A.; Durant, A.J.; Pyle, D.M.; Pearce, N.J.G. Ultra-distal tephra deposits from super-eruptions: Examples from Toba, Indonesia and Taupo Volcanic Zone, New Zealand. Quat. Int. 2012, 258, 54-79. [CrossRef]

176. Alloway, B.V.; McGlone, M.S.; Neall, V.E.; Vucetich, C.G. The role of Egmont-sourced tephra in evaluating the paleoclimatic corresspondence between the bio- and soil-stratigraphic records of central Taranaki, New Zealand. Quat. Int. 1992, 13-14, 187-194. [CrossRef]

177. Palmer, A.S.; Pillans, B.J. Record of climatic fluctuations from ca. 500 ka loess deposits and paleosols near Wanganui, New Zealand. Quat. Int. 1996, 34-36, 155-162. [CrossRef]

178. Williams, P.W.; McGlone, M.S.; Neil, H.; Zhao, J.-X. A review of New Zealand palaeoclimate from the last interglacial to the global last glacial maximum. Quat. Sci. Rev. 2015, 110, 92-106. [CrossRef]

179. Newnham, R.M.; Alloway, B.V.; McGlone, M.S.; Juchnowicz, H.; Rees, A.; Wilmshurst, J. A Last Interglacial pollen-temperature reconstruction, central North Island, New Zealand. Quat. Sci. Rev. 2017, 170, 136-151. [CrossRef]

180. Newnham, R.M.; Alloway, B.V. The last interglacial/glacial cycle in Taranaki, western North Island, New Zealand: A palynostratigraphic model. In Proceedings of the IX International Palynological Congress, Houston, TX, USA, 23-28 June 1996; Goodman, D.K., Clarke, R.T., Eds.; American Association of Stratigraphic Palynologists Foundation: Houston, TN, USA, 2001; pp. 411-422.

181. Newnham, R.M.; Alloway, B.V. A terrestrial record of Last Interglacial climate preserved by voluminous debris avalanche inundation in Taranaki, New Zealand. J. Quat. Sci. 2004, 19, 299-314. [CrossRef]

182. Newnham, R.M.; McGlone, M.S.; Moar, N.; Wilmshurst, J.M.; Vandergoes, M.J. The vegetation cover of New Zealand at the Last Glacial Maximum. Quat. Sci. Rev. 2013, 74, 202-214. [CrossRef]

183. Barrell, D.J.A. Quaternary glaciers of New Zealand. In Quaternary Glaciations-Extent and Chronology; Ehlers, J., Gibbard, P.L., Hughes, P.D., Eds.; Developments in Quaternary Science; Elsevier: Amsterdam, The Netherlands, 2011; Volume 15, pp. 1047-1064.

184. Danišík, M.; Schmitt, A.K.; Stockli, D.F.; Lovera, O.M.; Dunkl, I.; Evans, N.J. Application of combined U-Th-disequilibrium/U-Pb and (U-Th)/He zircon dating to tephrochronology. Quat. Geochronol. 2017, 40, 23-32. [CrossRef]

185. McWilliams, M. Global correlation of the 223 ka Pringle Falls Event. Int. Geol. Rev. 2001, 43, 191-195. [CrossRef]

186. Froggatt, P.C. Paleomagnetism of Last Glacial loess from two sections in New Zealand. In Loess: Its Distribution, Geology and Soils; Eden, D.N., Furkert, R.J., Eds.; CRC Press: Boca Raton, FL, USA, 1988; pp. 59-68. 
187. Pillans, B.J.; Wright, I. 500,000-year paleomagnetic record from New Zealand loess. Quat. Res. 1990, 33, 178-187. [CrossRef]

188. Shane, P.; Black, T.J.; Westgate, J.A. Isothermal plateau fission-track age for a paleomagnetic excursion in the Mamaku Ignimbrite, New Zealand and implications for Late Quaternary stratigraphy. Geophys. Res. Lett. 1994, 21, 1695-1698. [CrossRef]

189. Lal, C.; Channell, J.E.T. Geomagnetic excursions. In Treatise on Geophysics, 2nd ed.; Schubert, G., Ed.; Elsevier: Amsterdam, The Netherlands, 2015; Volume 5, pp. 343-383.

190. Horrocks, J.L.; Lowe, D.J.; Nelson, C.S.; Briggs, R.M. Characterising weathered tephras: Microprobe analysis of glass inclusions in quartz grains. (Abstract). Geol. Soc. N. Z. Misc. Publ. 1999, 107A, 72.

191. Birrell, K.S.; Stevens, K.F.; Vucetich, C.G. Late Quaternary sections containing tephra and loess in the Te Kuiti district, New Zealand. Geol. Dep. Vic. Univ. Wellingt. Publ. 1981, 20, 5-10.

192. Ruhe, R.V.; Olson, C.G. Soil welding. Soil Sci. 1980, 130, 132-139. [CrossRef]

193. De Deckker, P.; Arnold, L.J.; van der Kaars, S.; Bayon, G.; Stuut, J.-B.W.; Perner, K.; Lopes dos Santos, R.; Uemura, R.; Demuro, M. Marine Isotope Stage 4 in Australasia: A full glacial culminating 65,000 years ago-Global connections and implications for human dispersal. Quat. Sci. Rev. 2019, 204, 187-207. [CrossRef]

(C) 2019 by the author. Licensee MDPI, Basel, Switzerland. This article is an open access article distributed under the terms and conditions of the Creative Commons Attribution (CC BY) license (http:/ / creativecommons.org/licenses/by/4.0/). 